OPEN ACCESS

Edited by:

Giorgia Sollai,

University of Cagliari, Italy

Reviewed by:

Luigi Angelo Vaira,

Azienda Ospedaliero Universitaria

Sassari, Italy

Önder Göktas,

HNO Zentrum am Kudamm, Germany

*Correspondence:

Dawei Wu

davidwuor@163.com

Yongxiang Wei

yongxw67@163.com

Specialty section:

This article was submitted to

Perception Science,

a section of the journal

Frontiers in Neuroscience

Received: 12 May 2021

Accepted: 28 June 2021

Published: 12 August 2021

Citation:

Yuan F, Huang T, Wei Y and Wu D (2021) Steroids and Olfactory Training for Postviral Olfactory Dysfunction: A Systematic Review.

Front. Neurosci. 15:708510

doi: 10.3389/fnins.2021.708510

\section{Steroids and Olfactory Training for Postviral Olfactory Dysfunction: A Systematic Review}

\author{
Fan Yuan ${ }^{1}$, Tianhao Huang ${ }^{1}$, Yongxiang $W_{e} i^{1,2 *}$ and Dawei Wu ${ }^{1 *}$ \\ ${ }^{1}$ Department of Otolaryngology, Smell and Taste Center, Beijing Anzhen Hospital, Capital Medical University, Beijing, China, \\ ${ }^{2}$ Department of Otorhinolaryngology Head and Neck Surgery, Capital Institute of Pediatrics, Beijing, China
}

Background: Postviral olfactory dysfunction (PVOD) is a clinical challenge due to limited therapeutic options and poor prognosis. Both steroids and olfactory training have been proved to be effective for olfactory dysfunction with varied etiologies. We sought to perform a systematic review to summarize the evidence of steroids or olfactory training for patients with PVOD.

Methods: A systematic literature review using PubMed, Embase, Cochrane Library, and Web of Science was conducted to identify studies assessing olfactory change in patients with PVOD receiving steroid or olfactory training.

Results: Of the initial 273 abstracts reviewed, 20 articles with data from 2,415 patients with PVOD were included. Treatments including topical steroids, systemic steroids, classical olfactory training (COT), modified olfactory training (MOT), and olfactory training with steroid were analyzed. Both psychophysical olfactory testing and subjective symptom scores were utilized to assess the olfactory function. The routine use of nasal steroid spray alone during the management of PVOD seems to have no positive effect on olfactory dysfunction. Direct injection of steroid or nasal steroid spray into the olfactory cleft significantly improved the olfactory function in patients with PVOD. Olfactory improvement is greater than that of the natural course of the disease with short-term COT. Patients with PVOD would benefit more from long-term COT ( $>12$ weeks). Treatment duration, various odorants, olfactory training devices, changing the types of odors periodically, different molecular odorants, and different concentrations of odorants tended to increase the efficiency of MOT. Clinically significant improvement after olfactory training was defined as an increase of threshold, discrimination, and identification (TDI) score $\geq 6$. From week 24 to week 36, both COT and MOT groups reached the maximum therapeutic effect regarding the number of participants achieving clinically significant improvement. A combination of local or oral steroids with olfactory training is more efficient than COT only.

Conclusion: Olfactory function in patients with PVOD was effectively improved through direct steroid administration in the olfactory cleft, COT, or modification of COT. The addition of topical steroids to COT therapy showed a tendency for greater olfactory improvement in patients with PVOD. 


\section{INTRODUCTION}

Olfaction, together with vision, hearing, taste, and touch, constitutes the special sensory function of human beings, which has the effects of discriminating odors, increasing appetite, and warning, and is the primary tool for human understanding and cognition of the outside world like vision and hearing. There are numerous etiologies of olfactory dysfunction. Among them, sinonasal disease (30\%), upper respiratory tract infection (URTI) (25\%), and head trauma (14\%) are the most common causes of olfactory dysfunction, followed by idiopathic causes (12\%), congenital anosmia (3\%), or others (16\%) (Temmel et al., 2002; Hummel et al., 2017a; Schäfer et al., 2021).

Postviral olfactory dysfunction (PVOD) occurs after a common or epidemic URTI and is generally considered to be caused by a viral infection (Temmel et al., 2002; Seiden, 2004; Welge-Lüssen and Wolfensberger, 2006). Olfactory dysfunction has been noted as a common symptom in 18 to $22 \%$ of cases attributed to viral etiology (Tian et al., 2020). At present, the novel coronavirus disease 2019 (COVID-19) is caused by severe acute respiratory syndrome coronavirus 2 (SARS-CoV-2) infection and proves to have smell and taste loss (Printza et al., 2021). This pandemic has regained interest in PVOD and the related treatment.

A variety of drugs were reported in the literature for the treatment of PVOD, which were confirmed to affect including corticosteroids, vitamin A, Ginkgo biloba extract, and sodium citrate (Seo et al., 2009; Jiang et al., 2015; Hummel et al., 2017b; Whitcroft et al., 2017). Both oral and intranasal corticosteroids significantly improve olfactory function in patients with olfactory dysfunction with varied etiologies (Schriever et al., 2012; Kim et al., 2017; Nguyen and Patel, 2018). Meanwhile, olfactory training is currently the non-medical treatment supported by level $1 \mathrm{~A}$ evidence which was proved to have a significant improvement on olfactory function in patients with olfactory disorders (Hummel et al., 2009; Patel, 2017). These treatments gained widespread acceptance and were included in treatment guidelines for PVOD (Sorokowska et al., 2017; Kattar et al., 2020; Addison et al., 2021). The objective of this systematic review was to summarize the current evidence of steroids or olfactory training in PVOD, especially a combination of steroids and olfactory training.

\section{MATERIALS AND METHODS}

\section{Literature Search Strategy}

A systematic search of PubMed, Cochrane Library, Embase, Google Scholar, and Web of Science databases was conducted

Abbreviations: PVOD, postviral olfactory dysfunction; URTI, upper respiratory tract infection; COVID-19, novel coronavirus disease 2019; SARS-CoV-2, severe acute respiratory syndrome coronavirus 2; PRISMA, preferred reporting items for systematic reviews and meta-analyses; BTT, butanol threshold testing; CCSIT, cross-cultural smell identification test; CCCRC, connecticut chemosensory clinical research center test; T\&T, toyota \& takagi olfactometer; UPSIT, university of pennsylvania smell identification test; PEA, phenyl ethyl alcohol threshold testing; VAS, visual analog scale; COT, classical olfactory training; MOT, modified olfactory training; MCID, minimal clinically important difference. on October 1, 2020. Two investigators (F.Y. and D.W.) independently reviewed the titles and abstracts of all studies, making the articles meet our criteria for inclusion. A combination of the following search algorithm was used in this review: postviral olfactory dysfunction, postviral anosmia, postinfectious olfactory dysfunction, post-infectious olfactory loss, or postviral olfactory disorder and olfactory therapy, olfactory training, smell training, smell therapy, steroid, systemic steroid, topical steroid, or local steroid. The search strategy is illustrated in Figure 1. This systematic review was conducted according to the Preferred Reporting Items for Systematic Reviews and Meta-analyses (PRISMA) statement (Moher et al., 2009). The systematic search was not restricted to any specific study or publication type to ensure a thorough evaluation of the literature.

\section{Inclusion and Exclusion Criteria}

Studies exploring the effects of steroids, olfactory training, or both interventions on olfaction in patients with PVOD were included. Changes in olfactory scores or rates of patients with treatment response should be reported and abstracts containing subjects with postviral olfactory dysfunction and other etiologies of olfactory dysfunction were also included. Exclusion criteria included non-English language and patient populations composed exclusively of those with olfactory dysfunction secondary to etiologies other than viral infection (e.g., idiopathic, trauma, and chronic rhinosinusitis). Studies without a defined intervention were excluded. In addition, case reports, letters to the editor, abstracts, and book chapters were not included.

\section{Data Extraction and Analysis}

Two reviewers (F.Y. and D.W.) each manually extracted data from studies meeting inclusion criteria. Extracted data included descriptive baseline characteristics, intervention data (regimen and duration), follow-up, and olfactory outcomes. Summary tables were developed after the extraction of articles. The quality of each article was assessed by the Oxford Center for EvidenceBased Medicine Levels of Evidence categorization (Burns et al., 2011).

\section{RESULTS}

\section{Study Characteristics}

Our search identified 273 studies that met the inclusion criteria through the initial literature (Figure 1). After the removal of duplicates and abstract screening, 245 articles were excluded. Of these remaining 28 studies, 8 studies were excluded due to the following reasons: not examining postviral olfactory dysfunction $(n=2)$, lacking quantifiable data $(n=2)$, no assessment for the olfactory outcome $(n=2)$, no specified therapy $(n=1)$, and short follow-up $(n=1)$. Finally, 20 articles were included in the systematic review.

\section{Trial Characteristics}

A total of 2,415 patients with olfactory dysfunction were included and $60.1 \%(1,451)$ of patients were PVOD. The severity of olfactory dysfunction ranged from hyposmia to anosmia. 


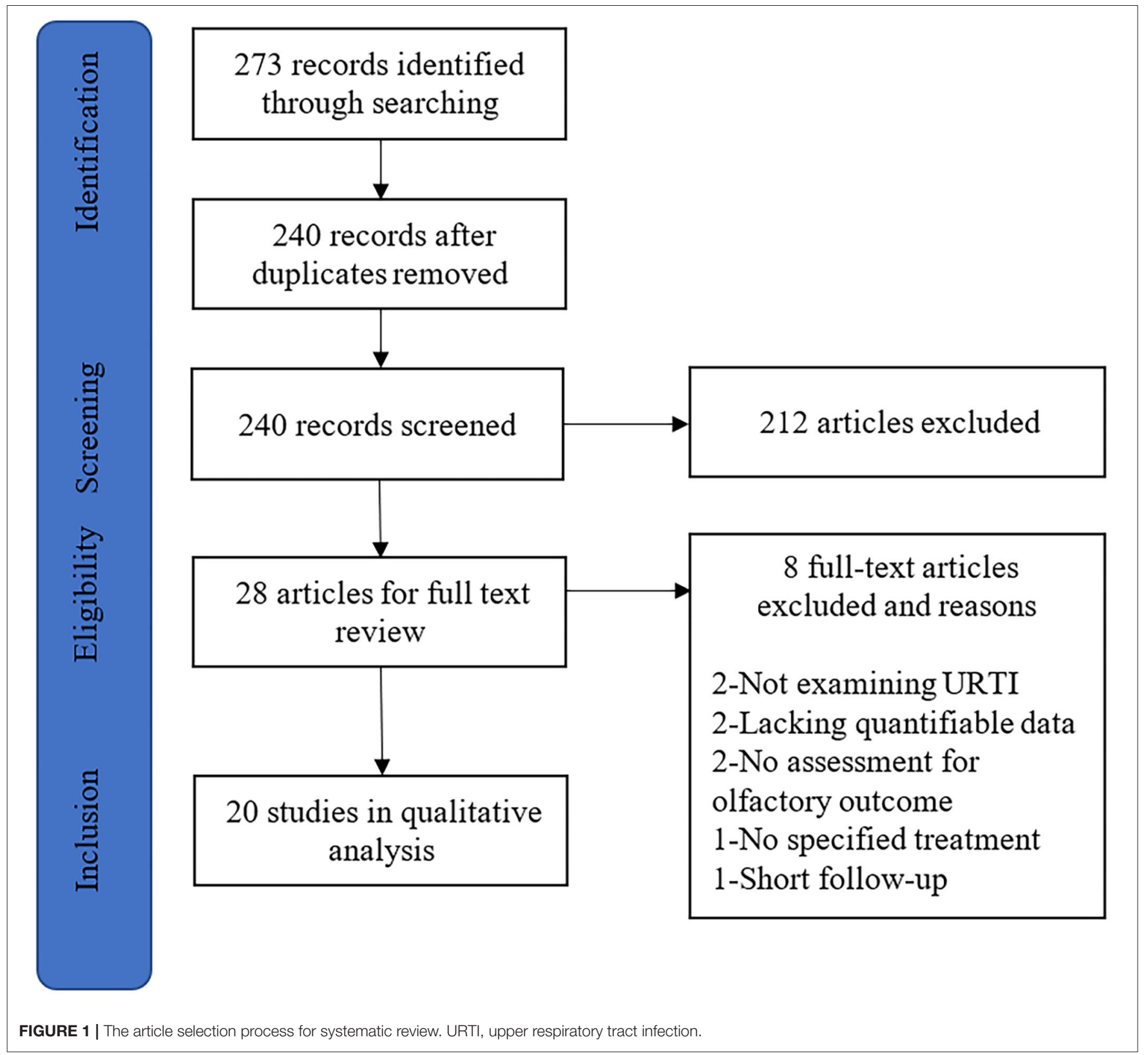

Olfactory outcomes assessed in 20 studies utilized Sniffin' Sticks, butanol threshold testing (BTT), Cross-Cultural Smell Identification Test (CCSIT), Connecticut Chemosensory Clinical Research Center test (CCCRC), Toyota \& Takagi olfactometer (T\&T), University of Pennsylvania Smell Identification Test (UPSIT), phenyl ethyl alcohol (PEA) threshold testing, and visual analog scale (VAS). The length of follow-up varied from half a month to 12 months. Treatment measures included topical steroids, systemic steroids, classical olfactory training (COT), and modified olfactory training (MOT). COT was defined as the regimen firstly described by Hummel et al., which involved twicedaily exposure to a set of four odors, including rose, eucalyptus, lemon, and cloves, from media such as brown jars or markers. To define the treatment response, olfactory improvement was considered with a decrease in recognition threshold score (T\&T) $>1$ point, an increase in BTT score $\geq 3$, an increase in CCSIT score $\geq 3$, an increase in Sniffin' Sticks score $\geq 5.5$ or $\geq 6$, and an increase in UPSIT score $\geq 5$. Minimal clinically important difference (MCID) was defined as a $\geq 6$ increase in TDI scores (Jaeschke et al., 1989). Seventeen out of the 20 included articles had control groups and all articles were statistically analyzed.

\section{Systemic and Topical Steroids}

Four trials used oral steroids with other control treatments and two trials used topical steroids alone (Table 1) (Heilmann et al., 2004; Fukazawa, 2005; Seo et al., 2009; Fleiner and Goktas, 2011; Schriever et al., 2012; Vaira et al., 2021). Of these trials following systemic steroids, two studies evaluated patients with PVOD and 
TABLE 1 | Summary of topical and systemic steroid studies included in the systematic review.

\begin{tabular}{|c|c|c|c|c|c|c|c|c|c|}
\hline References & Design & Patients & Intervention & $\begin{array}{l}\text { Treatment } \\
\text { details }\end{array}$ & $\begin{array}{l}\text { The time of } \\
\text { initiation of } \\
\text { therapy }\end{array}$ & $\begin{array}{l}\text { Follow- } \\
\text { up }\end{array}$ & Improvement & Conclusion & $\begin{array}{l}\text { Level of } \\
\text { evidence }\end{array}$ \\
\hline $\begin{array}{l}\text { Heilmann } \\
\text { et al. (2004) }\end{array}$ & $\begin{array}{l}\text { Retrospective, } \\
\text { non- } \\
\text { randomized, } \\
\text { parallel-group } \\
\text { case series }\end{array}$ & $\begin{array}{l}\text { Systemic steroids } \\
\text { group }(n=12) \text { vs. } \\
\text { Topical steroids } \\
\text { group }(n=10) \\
\text { All PVOD }\end{array}$ & $\begin{array}{l}\text { (1) Oral } \\
\text { prednisolone } \\
\text { (2) Mometasone } \\
\text { spray }\end{array}$ & $\begin{array}{l}\text { (1) Prednisolone } \\
40 \mathrm{mg} \times 21 \text {-day } \\
\text { taper } \\
(2) \text { Mometasone } \\
0.1 \mathrm{mg} / \text { nasal } \\
\text { cavity } \times 1-3 \\
\text { months }\end{array}$ & $\begin{array}{l}5.7 \text { years after } \\
\text { clinical onset }\end{array}$ & $\begin{array}{l}21-330 \\
\text { days }\end{array}$ & $\begin{array}{l}\text { Sniffin' Sticks } \\
\text { Systemic steroids } \\
\text { group } \\
\text { Threshold: } 2.7 \text { to } 3.8 \\
\text { Discrimination: } 7 \text { to } 8.9 \\
\text { Identification: } 5.4 \text { to } 6.9 \\
\text { The mean TDI score: } \\
15.2 \text { to } 19.6 \\
\text { Topical steroids group } \\
\text { Threshold: } 4.2 \text { to } 4.5 \\
\text { Discrimination: } 8.3 \text { to } \\
8.7 \\
\text { Identification: } 7.4 \text { to } 6.4 \\
\text { The mean TDI score: } \\
20 \text { to } 19.6\end{array}$ & $\begin{array}{l}\text { Topical application of } \\
\text { steroids appears to } \\
\text { have no positive effect } \\
\text { on olfactory } \\
\text { dysfunction, apart from } \\
\text { a tendency of improved } \\
\text { odor threshold and } \\
\text { discrimination. } \\
\text { Systemic steroids lead } \\
\text { to improvement of } \\
\text { olfactory function. } \\
\text { No statistical difference } \\
\text { between systemic and } \\
\text { topical steroids }\end{array}$ & 4 \\
\hline $\begin{array}{l}\text { Schriever } \\
\text { et al. (2012) }\end{array}$ & $\begin{array}{l}\text { Retrospective } \\
\text { case series }\end{array}$ & $\begin{array}{l}\text { Systemic steroids } \\
\text { PVOD: } 27 / 425 \\
\text { Sinonasal }(n= \\
221) \\
\text { Idiopathic ( } n= \\
\text { 157) } \\
\text { Other causes ( } n \\
=20 \text { ) }\end{array}$ & $\begin{array}{l}\text { Oral } \\
\text { methylprednisolone } \\
\text { (all) }\end{array}$ & $\begin{array}{l}\text { Methylprednisolone } \\
40 \mathrm{mg} \text { daily with } \\
\text { taper }\end{array}$ & $\begin{array}{l}5.6 \text { years after } \\
\text { clinical onset }\end{array}$ & 2 weeks & $\begin{array}{l}\text { An increase in Sniffin' } \\
\text { Sticks score } \geq 6 \\
\text { PVOD etiology: } 29.6 \% \\
\text { The TDI scores } \\
\text { improved from } 14.39 \text { to } \\
18.86(p=0.003)\end{array}$ & $\begin{array}{l}\text { PVOD patients } \\
\text { exhibited clinically } \\
\text { significant improvement } \\
\text { in TDI after treatment } \\
\text { with systemic steroids. }\end{array}$ & 4 \\
\hline $\begin{array}{l}\text { Fukazawa } \\
\text { (2005) }\end{array}$ & $\begin{array}{l}\text { Prospective, } \\
\text { non- } \\
\text { controlled } \\
\text { case series }\end{array}$ & $\begin{array}{l}\text { All PVOD } \\
(n=133)\end{array}$ & $\begin{array}{l}\text { Dexamethasone } \\
\text { or betamethasone } \\
\text { (all) }\end{array}$ & $\begin{array}{l}\text { Dexamethasone } \\
5 \mathrm{mg} \text { or } \\
\text { betamethasone } \\
5 \mathrm{mg} \text { injections } \\
\text { into olfactory cleft } \\
\text { every } 2 \text { weeks for } \\
16-20 \text { weeks }\end{array}$ & - & 6 months & $\begin{array}{l}\text { T\&T score } \\
\text { improvement at least } \\
\text { one point in odor } \\
\text { recognition threshold: } \\
\text { PVOD: } 49.6 \% \\
\text { The mean points of } \\
\text { VAS improved from } \\
10.2 \text { at pretreatment to } \\
39.5 \text { after } \\
\text { the treatment. }\end{array}$ & $\begin{array}{l}\text { Injecting the steroid } \\
\text { into the nasal mucosa } \\
\text { near the olfactory cleft } \\
\text { demonstrated to } \\
\text { improve the points of } \\
\text { T\&T olfactometry. }\end{array}$ & 4 \\
\hline $\begin{array}{l}\text { Fleiner and } \\
\text { Goktas (2011) }\end{array}$ & $\begin{array}{l}\text { Prospective } \\
\text { case series }\end{array}$ & PVOD: 8/18 & $\begin{array}{l}\text { Beclomethasone } \\
\text { spray (all) }\end{array}$ & $\begin{array}{l}\text { Beclomethasone } \\
\text { spray } 250 \mu \mathrm{g} \\
\text { directed to the } \\
\text { olfactory cleft } \\
\text { twice daily }\end{array}$ & $\begin{array}{l}2.3 \text { months } \\
\text { after clinical } \\
\text { onset }\end{array}$ & 4 weeks & $\begin{array}{l}\text { An increase in Sniffin' } \\
\text { Sticks score } \geq 6 \text { : } \\
\text { PVOD: } 25 \% \\
\text { The mean TDI score: } \\
13.5 \text { to } 18.5\end{array}$ & $\begin{array}{l}\text { The direct application } \\
\text { of BDP-spray to the } \\
\text { olfactory cleft attained } \\
\text { superior therapeutic } \\
\text { effects than a usually } \\
\text { applied mometasone } \\
\text { spray. }\end{array}$ & 4 \\
\hline
\end{tabular}


TABLE 1 | Continued

\begin{tabular}{|c|c|c|c|c|c|c|c|c|c|}
\hline References & Design & Patients & Intervention & $\begin{array}{l}\text { Treatment } \\
\text { details }\end{array}$ & $\begin{array}{l}\text { The time of } \\
\text { initiation of } \\
\text { therapy }\end{array}$ & $\begin{array}{l}\text { Follow- } \\
\text { up }\end{array}$ & Improvement & Conclusion & $\begin{array}{l}\text { Level of } \\
\text { evidence }\end{array}$ \\
\hline $\begin{array}{l}\text { Seo et al. } \\
\text { (2009) }\end{array}$ & $\begin{array}{l}\text { Randomized, } \\
\text { non-blinded, } \\
\text { parallel group }\end{array}$ & $\begin{array}{l}\text { No Ginkgo biloba } \\
\text { group }(n=28) \text { vs. } \\
\text { With G. biloba } \\
\text { group }(n=43) \\
\text { All PVOD }\end{array}$ & $\begin{array}{l}\text { (1) Oral } \\
\text { prednisolone }+ \\
\text { mometasone spray } \\
\text { (2) Oral } \\
\text { prednisolone + } \\
\text { mometasone } \\
\text { spray + G. biloba }\end{array}$ & $\begin{array}{l}\text { (1) Prednisolone } \\
30 \mathrm{mg} \text { daily with } \\
\text { taper } \\
\text { (2) Mometasone } \\
\text { two puffs/nasal } \\
\text { cavity twice daily } \\
\text { (3) G. biloba } 80 \mathrm{mg} \\
\text { three times daily }\end{array}$ & $\begin{array}{l}3.5 \text { months } \\
\text { after clinical } \\
\text { onset }\end{array}$ & 4 weeks & $\begin{array}{l}\text { An increase in BTT } \\
\text { score } \geq 3 \text { : } \\
\text { No G. biloba group: } \\
32 \% \\
\text { With G. biloba group: } \\
37 \% \\
\text { Mean odor threshold: } \\
4.8 \text { to } 6.7 \\
\text { An increase in CCSIT } \\
\text { score } \geq 3 \text { : } \\
\text { No G. biloba group: } \\
14 \% \\
\text { With G. biloba group: } \\
33 \% \\
\text { Mean odor } \\
\text { identification: } 3.8 \text { to } 5.3\end{array}$ & $\begin{array}{l}\text { Combination therapy } \\
\text { with oral prednisolone } \\
\text { and G. biloba did not } \\
\text { show significantly } \\
\text { better efficacy than } \\
\text { monotherapy with oral } \\
\text { prednisolone. } \\
\text { G. biloba might help } \\
\text { improve odor } \\
\text { identification. }\end{array}$ & $2 \mathrm{~B}$ \\
\hline $\begin{array}{l}\text { Vaira et al. } \\
\text { (2021) }\end{array}$ & $\begin{array}{l}\text { Prospective, } \\
\text { randomized } \\
\text { controlled trial }\end{array}$ & $\begin{array}{l}\text { Control group }(n= \\
\text { 9) vs. Systemic } \\
\text { prednisone and } \\
\text { nasal irrigation } \\
\text { group }(n=9) \\
\text { All PVOD }\end{array}$ & $\begin{array}{l}\text { (1) No treatment } \\
\text { (2) Systemic } \\
\text { prednisone and } \\
\text { nasal irrigation } \\
\text { with } \\
\text { betamethasone, } \\
\text { ambroxol, } \\
\text { and rinazine }\end{array}$ & $\begin{array}{l}\text { Systemic } \\
\text { cortisone therapy } \\
\text { with prednisone, } \\
\text { starting with } 1 \\
\mathrm{mg} / \mathrm{kg} / \text { day and } \\
\text { tapering the dose } \\
\text { for } 15 \text { days and } \\
\text { nasal irrigation } \\
\text { with } \\
\text { betamethasone, } \\
\text { ambroxol, a } \\
\text { mucolytic, and } \\
\text { rinazine, a } \\
\text { decongestant, for } \\
15 \text { days. }\end{array}$ & $\begin{array}{l}1 \text { month after } \\
\text { clinical onset }\end{array}$ & 40 days & $\begin{array}{l}\text { The threshold and } \\
\text { identification test } \\
\text { scores were finally } \\
\text { converted into the } \\
\text { CCCRC composite } \\
\text { score which allows } \\
\text { classifying the olfactory } \\
\text { function of patients in } \\
\text { normal (score } 90 \text { and } \\
100) \text {, mild hyposmia } \\
\text { (score } 70 \text { and } 80 \text { ), } \\
\text { moderate hyposmia } \\
\text { (score } 50 \text { and } 60) \text {, } \\
\text { severe hyposmia (score } \\
\text { between } 20 \text { and } 40) \text {, } \\
\text { and anosmia (score } 0 \\
\text { and } 10)(27-30) \text {. }\end{array}$ & $\begin{array}{l}\text { The mix of drugs } \\
\text { including steroids could } \\
\text { represent a useful } \\
\text { specific therapy to } \\
\text { reduce the prevalence } \\
\text { of this long-term } \\
\text { morbidity. }\end{array}$ & $1 \mathrm{~B}$ \\
\hline $\begin{array}{l}\text { Stenner et al. } \\
\text { (2008) }\end{array}$ & $\begin{array}{l}\text { Retrospective } \\
\text { case series }\end{array}$ & $\begin{array}{l}\text { Topical steroids } \\
\text { group vs. Topical } \\
\text { steroids + topical } \\
\text { antibiotics group } \\
\text { URTI: } 31 / 89\end{array}$ & $\begin{array}{l}\text { (1) Oral } \\
\text { betamethasone }+ \\
\text { budesonide spray } \\
\text { (2) Oral } \\
\text { betamethasone }+ \\
\text { budesonide spray } \\
+ \text { neomycin spray }\end{array}$ & $\begin{array}{l}\text { All patients treated } \\
\text { with } 20 \text { days oral } \\
\text { beclomethasone } \\
\text { (1) Betamethasone } \\
3.0 \mathrm{mg} \text { daily with } \\
\text { taper } \\
\text { (2) Budesonide } \\
\text { spray } 1.5 \mathrm{mg} \text { twice } \\
\text { daily } \\
\text { (3) Neomycin } \\
\text { spray } 7.5 \mathrm{mg} \text { twice } \\
\text { daily }\end{array}$ & $\begin{array}{l}4.6 \text { years after } \\
\text { clinical onset }\end{array}$ & $\begin{array}{l}12 \\
\text { weeks }\end{array}$ & $\begin{array}{l}\text { The mean TDI of } 27 \% \\
\text { of patients improved } \\
\text { from } 15.5 \text { raised to } \\
18.7 \text { after the } \\
\text { experiment. }\end{array}$ & $\begin{array}{l}\text { No change with topical } \\
\text { treatment of both } \\
\text { steroids and antibiotics. } \\
\text { Oral steroids clinically } \\
\text { meaningfully improved } \\
\text { TDI for patients of all } \\
\text { etiologies. }\end{array}$ & 4 \\
\hline
\end{tabular}

PVOD, postviral olfactory dysfunction; CCCRC, connecticut chemosensory clinical research center test; BTT, butanol threshold test; CCSIT, cross-cultural smell identification Test; T\&T, toyota \& takagi olfactometer; TDI, threshold-discrimination-identification score; VAS, visual analog scale; BDP-spray, beclomethasone dipropionate spray. 
demonstrated a significant improvement of olfactory score and recovery rate after systemic steroids therapy alone (Heilmann et al., 2004; Schriever et al., 2012). The mean TDI score in patients with PVOD receiving oral steroids changed from 15.2 to 19.6 (Heilmann et al., 2004). Similarly, another study by Schriever et al. showed the TDI scores improved from 14.39 to 18.86 in patients with PVOD receiving oral steroids and $29.6 \%$ of patients with PVOD reported an increase of more than 6 points of the TDI score (Schriever et al., 2012).

About the local steroids, nasal spray and injection to the olfactory cleft were included. Four studies evaluated the effect of nasal spray or injection alone on the olfaction in patients with PVOD (Heilmann et al., 2004; Fukazawa, 2005; Stenner et al., 2008; Seo et al., 2009; Fleiner and Goktas, 2011; Vaira et al., 2021). A retrospective study by Heilmann et al. reported the effect of mometasone spray at $0.1 \mathrm{mg}$ twice daily for up to 3 months in patients with PVOD and there was no positive effect on olfactory dysfunction (Heilmann et al., 2004). Fukazawa et al. found injecting steroids into the nasal mucosa near the olfactory cleft significantly improved the T\&T score and $49.6 \%$ of patients achieved the decrease in recognition threshold $>1$ point (Fukazawa, 2005). Furthermore, a prospective study by Fleiner and Goktas showed an increased efficacy of twice-daily beclomethasone injection to the olfactory cleft when compared with mometasone spray alone, with $25 \%$ of PVOD patients achieving an increase of more than six points in the TDI score (Fleiner and Goktas, 2011). Two studies used steroids in combination with other drugs (Seo et al., 2009; Vaira et al., 2021). Both the combination therapy (oral steroid and nasal steroid spray) and mixed therapy (oral steroid, nasal steroid spray, and Ginkgo biloba) significantly increased the olfaction in patients with PVOD, while there was no significant difference in the treatment response (defined as a score increase in BTT score $\geq 3$ ) between these two treatment modalities (Seo et al., 2009). The novel therapy about systemic steroids and nasal irrigation with betamethasone, ambroxol, and prednisolone in patients with COVID-19 had been explored by Vaira et al. (2021). Compared with the no treatment group, the experimental group showed significant olfactory improvement in which the mean CCCRC score was from 10 to 60 . Another retrospective case series trial by Stenner et al. investigated the use of neomycin spray to treat olfactory disorders including PVOD (34.8\%) (Stenner et al., 2008). The administered regimen included beclomethasone at $3 \mathrm{mg}$ daily for 20 days and then patients were randomly assigned to budesonide spray $1.5 \mathrm{mg}$ twice daily vs. neomycin spray $7.5 \mathrm{mg}$ twice daily in the control group for 12 weeks. After the experiment, there was no difference in recovery rate with additional antibiotics compared with topical treatment.

In summary, the routine use of nasal steroid spray alone during the management of PVOD without combination with other treatments is not recommended. However, direct injection of steroid or nasal steroid spray into the olfactory cleft has been proved to be a promising therapy, which needed further studies. Although early evidence suggests that systemic steroids are more effective than intranasal steroid spray in patients with olfactory loss due to varied etiologies (Kim et al., 2017), a study by Heilmann et al. suggested that there was no statistical difference between systemic steroids and intranasal steroid spray in treating patients with PVOD (Heilmann et al., 2004). More RCTs are required before a recommendation on medical treatment can be provided.

\section{Classical Olfactory Training}

COT was firstly described by Hummel et al., which involved four odors including rose, eucalyptus, lemon, and cloves (Hummel et al., 2009). Patients usually smell each odorant for $10 \mathrm{~s}$ or longer twice daily until they have finished the entire set (Hummel et al., 2009). Five studies assessed the effect of COT in patients with PVOD (Table 2) (Hummel et al., 2009; Konstantinidis et al., 2013, 2016; Geißler et al., 2014; Gellrich et al., 2018).

Four of these trials compared COT to placebo with the followup varied from 8 to 56 weeks, and all the studies proved the efficiency of the COT on patients with PVOD (Hummel et al., 2009; Konstantinidis et al., 2013, 2016; Gellrich et al., 2018). Even for a short period of 12 weeks, the COT group provided relatively higher scores than to placebo which did not receive training (Hummel et al., 2009; Gellrich et al., 2018). The percentage of patients achieving MCID (defined as a $\geq 6$ increase in TDI scores) in the COT and control group was 20.8 and $0.9 \%$, respectively (Hummel et al., 2009). Another study by Konstantinidis et al. showed that patients achieving MCID in COT and control group were 67.8 and 33\%, respectively (Konstantinidis et al., 2013). The mean TDI scores significantly changed from 18.95 to 25.2 and patients with training benefit increased mainly their identification and discrimination scores (discrimination: 7.9 to 8.3, identification: 8.8 to 9.6) (Konstantinidis et al., 2013). Furthermore, another prospective and non-randomized study without control by Geißler et al. showed that the percentage of patients with PVOD achieving MCID was significantly higher after 32 weeks of olfactory training (79\%) than that after 16 weeks of olfactory training (56\%) (Geißler et al., 2014). A prospective, randomized controlled clinical trial by Konstantinidis et al. investigated different olfactory training duration in patients with PVOD (Konstantinidis et al., 2016). Patients with PVOD were exposed to four odors twice daily for 16 weeks (short-term group) or 56 weeks (long-term group) and compared with the no treatment group. Treatment response was defined as an increase of TDI scores $\geq 6$. This study found that the treatment response rates in the long-term group, short-term group, and control group were 71,58 , and $37 \%$, respectively. Besides, the long-term COT group had a significant increase in TDI score changing from 15.9 to 27.3. The MCID in COT showed a high rate with the increase of treatment time, reaching $79 \%$ in 32 weeks, but there had a tendency to decrease beyond 32 weeks which was $71 \%$ in 56 weeks (Figure 2).

In summary, short-term olfactory training results in sustainable olfactory improvement greater than that of the natural course of the disease. Given the positive results from multiple clinical studies, a recommendation is designated for long-term use (>12 weeks) for olfactory training in patients with PVOD. Furthermore, olfactory function sustained a fast recovery period and a second slower period after long-term olfactory training. 
TABLE 2 | Summary of classical olfactory training studies included in the systematic review.

\begin{tabular}{|c|c|c|c|c|c|c|c|c|c|}
\hline References & Design & Patients & Intervention & $\begin{array}{l}\text { Treatment } \\
\text { details }\end{array}$ & $\begin{array}{l}\text { The time of } \\
\text { initiation of } \\
\text { therapy }\end{array}$ & $\begin{array}{l}\text { Follow- } \\
\text { up }\end{array}$ & Improvement & Conclusion & $\begin{array}{l}\text { Level of } \\
\text { evidence }\end{array}$ \\
\hline $\begin{array}{l}\text { Hummel et al. } \\
\text { (2009) }\end{array}$ & $\begin{array}{l}\text { Prospective } \\
\text { controlled, } \\
\text { non-blinded } \\
\text { trial }\end{array}$ & $\begin{array}{l}\text { COT }(n=24) \text { vs. } \\
\text { Control group }(n= \\
11) \\
\text { PVOD: } 35 / 56 \\
\text { Post-traumatic: } \\
7 / 56 \\
\text { Idiopathic: } 14 / 56\end{array}$ & $\begin{array}{l}\text { (1) Classical } \\
\text { olfactory training } \\
\text { (2) Control group }\end{array}$ & $\begin{array}{l}\text { (1) Exposure to } \\
\text { four odors twice } \\
\text { daily } \\
\text { (2) No treatment }\end{array}$ & $\begin{array}{l}4.3 \text { years after } \\
\text { clinical onset }\end{array}$ & $\begin{array}{l}12 \\
\text { weeks }\end{array}$ & $\begin{array}{l}\text { An increase in Sniffin' } \\
\text { Sticks score } \geq 6 \\
\text { COT: } 20.8 \% \\
\text { Control: } 0.9 \%\end{array}$ & $\begin{array}{l}\text { Patients including } \\
\text { PVOD undergoing OT } \\
\text { exhibited significantly } \\
\text { higher scores than } \\
\text { patients who did not } \\
\text { train. }\end{array}$ & 4 \\
\hline $\begin{array}{l}\text { Gellrich et al. } \\
(2018)\end{array}$ & $\begin{array}{l}\text { Prospective } \\
\text { controlled trial }\end{array}$ & $\begin{array}{l}\text { COT }(n=30) \text { vs. } \\
\text { Control group }(n= \\
31) \\
\text { All PVOD }\end{array}$ & $\begin{array}{l}\text { (1) Classical } \\
\text { olfactory training } \\
\text { (2) Control group }\end{array}$ & $\begin{array}{l}\text { (1) Exposure to } \\
\text { four odors twice } \\
\text { daily } \\
\text { (2) No treatment }\end{array}$ & $\begin{array}{l}2.8 \text { years after } \\
\text { clinical onset }\end{array}$ & $\begin{array}{l}12 \\
\text { weeks }\end{array}$ & $\begin{array}{l}\text { An increase in Sniffin' } \\
\text { Sticks score } \geq 5.5 \\
\text { COT: } 53.3 \% \\
\text { Control: no data } \\
\text { COT group } \\
\text { Threshold: } 1.8 \text { to } 4 \\
\text { Discrimination: } 7.3 \text { to } \\
\text { 9.5 } \\
\text { Identification: } 7.3 \text { to } 9 \\
\text { The mean TDI score: } \\
16.4 \text { to } 21.9(p<0.01)\end{array}$ & $\begin{array}{l}\text { Even with the short } \\
\text { olfactory duration, the } \\
\text { points of Sniffin' Sticks } \\
\text { could significantly } \\
\text { enhance. }\end{array}$ & 4 \\
\hline $\begin{array}{l}\text { Konstantinidis } \\
\text { et al. (2013) }\end{array}$ & $\begin{array}{l}\text { Prospective } \\
\text { controlled trial }\end{array}$ & $\begin{array}{l}\text { COT }(n=49) \text { vs. } \\
\text { Control group }(n= \\
\text { 32) } \\
\text { PVOD: } 81 / 119 \\
\text { Post- } \\
\text { traumatic: } 38 / 119\end{array}$ & $\begin{array}{l}\text { (1) Classical } \\
\text { olfactory training } \\
\text { (2) Control group }\end{array}$ & $\begin{array}{l}\text { (1) Exposure to } \\
\text { four odors twice } \\
\text { daily } \\
\text { (2) No treatment }\end{array}$ & $\begin{array}{l}10 \text { months } \\
\text { after clinical } \\
\text { onset }\end{array}$ & $\begin{array}{l}16 \\
\text { weeks }\end{array}$ & $\begin{array}{l}\text { An increase in Sniffin' } \\
\text { Sticks score } \geq 6 \\
\text { Week } 16 \\
\text { COT: } 67.8 \% \\
\text { Control: } 33 \% \\
\text { COT group } \\
\text { Threshold: } 2.3 \text { to } 2.6 \\
\text { Discrimination: } 7.9 \text { to } \\
\text { 8.3 } \\
\text { Identification: } 8.8 \text { to } 9.6 \\
\text { The mean TDI score: } \\
18.95 \text { to } 25.2 \text { ( } p< \\
\text { 0.001) } \\
\text { Control group } \\
\text { Threshold: } 2.4 \text { to } 2.5 \\
\text { Discrimination: } 7.8 \text { to } \\
10.4 \\
\text { Identification: } 8.6 \text { to } \\
12.2 \\
\text { The mean TDI score: } \\
19 \text { to } 20.5 \text { ( } p>0.001)\end{array}$ & $\begin{array}{l}\text { Patients with training } \\
\text { benefit increased } \\
\text { mainly their } \\
\text { identification and } \\
\text { discrimination scores; a } \\
16 \text {-week short-term } \\
\text { exposure to specific } \\
\text { odors may increase } \\
\text { olfactory sensitivity in } \\
\text { patients with PVOD. }\end{array}$ & 4 \\
\hline
\end{tabular}


TABLE 2 | Continued

\begin{tabular}{|c|c|c|c|c|c|c|c|c|c|}
\hline References & Design & Patients & Intervention & $\begin{array}{l}\text { Treatment } \\
\text { details }\end{array}$ & $\begin{array}{l}\text { The time of } \\
\text { initiation of } \\
\text { therapy }\end{array}$ & $\begin{array}{l}\text { Follow- } \\
\text { up }\end{array}$ & Improvement & Conclusion & $\begin{array}{l}\text { Level of } \\
\text { evidence }\end{array}$ \\
\hline $\begin{array}{l}\text { Geißler et al. } \\
\text { (2014) }\end{array}$ & $\begin{array}{l}\text { Prospective, } \\
\text { non- } \\
\text { randomized } \\
\text { case series }\end{array}$ & All PVOD $(n=39)$ & $\begin{array}{l}\text { Classical olfactory } \\
\text { training (all) }\end{array}$ & $\begin{array}{l}\text { Exposure to four } \\
\text { odors twice daily }\end{array}$ & $\begin{array}{l}10 \text { months } \\
\text { after clinical } \\
\text { onset }\end{array}$ & $\begin{array}{l}16 \text { and } \\
32 \\
\text { weeks }\end{array}$ & $\begin{array}{l}\text { An increase in Sniffin' } \\
\text { Sticks score } \geq 6 \text { : } \\
\text { PVOD } \\
\text { Week 16: } \\
\text { COT: } 56 \% \\
\text { Week } 32: \\
\text { COT: } 79 \% \\
\text { Week } 32 \\
\text { Threshold: } 1 \text { to } 2 \\
\text { Discrimination: } 8 \text { to } 10 \\
\text { Identification: } 8 \text { to } 9 \\
\text { The mean TDI score: } \\
17 \text { to } 21(p=0.021)\end{array}$ & $\begin{array}{l}\text { A longer duration of } \\
\text { training could increase } \\
\text { the effectiveness of } \\
\text { training in comparison } \\
\text { with a shorter training } \\
\text { period. }\end{array}$ & 4 \\
\hline $\begin{array}{l}\text { Konstantinidis } \\
\text { et al. (2016) }\end{array}$ & $\begin{array}{l}\text { Prospective, } \\
\text { randomized } \\
\text { controlled trial }\end{array}$ & $\begin{array}{l}\text { Long-term training } \\
\text { group }(n=34) \text { vs. } \\
\text { Short-term training } \\
\text { group }(n=36) \\
\text { vs. } \\
\text { Control group ( } n= \\
\text { 41) } \\
\text { All PVOD }\end{array}$ & $\begin{array}{l}\text { (1) Classical } \\
\text { olfactory training } \\
\text { (2) Control group }\end{array}$ & $\begin{array}{l}\text { Exposure to four } \\
\text { odors twice daily } \\
\text { (1) OT for } 56 \\
\text { weeks } \\
\text { (2) OT for } 16 \\
\text { weeks } \\
\text { (3) No treatment }\end{array}$ & $\begin{array}{l}9 \text { months } \\
\text { after clinical } \\
\text { onset }\end{array}$ & $\begin{array}{l}56 \\
\text { weeks }\end{array}$ & $\begin{array}{l}\text { An increase in Sniffin' } \\
\text { Sticks score } \geq 6 \\
\text { Long: } 71 \% \\
\text { Short: } 58 \% \\
\text { Control: } 37 \% \\
\text { Long-term group } \\
\text { Threshold: } 2.1 \text { to } 2.7 \\
\text { Discrimination: } 5.3 \text { to } \\
10.2 \\
\text { Identification: } 8.1 \text { to } \\
14.4 \\
\text { The mean TDI score: } \\
15.9 \text { to } 27.3(p<0.05)\end{array}$ & $\begin{array}{l}\text { Short-term olfactory } \\
\text { training results in } \\
\text { sustainable olfactory } \\
\text { improvement greater } \\
\text { than that of the natural } \\
\text { course of the disease. } \\
\text { Long-term olfactory } \\
\text { training presented an } \\
\text { improvement of } \\
\text { olfactory function with a } \\
\text { first fast recovery } \\
\text { period of } 16 \text { weeks and } \\
\text { a second slower period } \\
\text { of } 40 \text { weeks. }\end{array}$ & $1 \mathrm{~B}$ \\
\hline
\end{tabular}

$P V O D$, postviral olfactory dysfunction; OT, olfactory training; COT, classic olfactory training; MOT, modified olfactory training. 


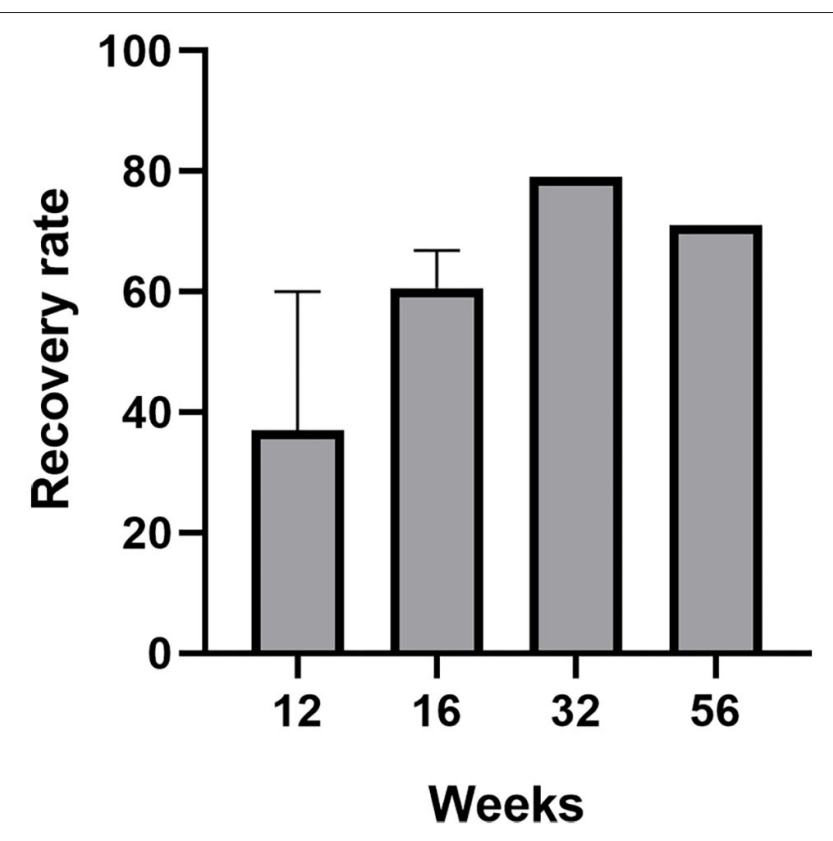

FIGURE 2 | The recovery rate (defined as an increased $\geq 6$ in TDI score) of patients with PVOD who used classical olfactory training with different treatment duration $(12,16,32$, and 56 weeks).

\section{Modified Olfactory Training}

Four randomized controlled and one pseudorandomized study used modifications of the COT, including different concentrations of odorants, different molecular odorants, various odorants, and olfactory balls (Table 3) (Damm et al., 2014; Altundag et al., 2015; Poletti et al., 2017; Qiao et al., 2020; Saatci et al., 2020). Two RCTs without a placebo group compared two different types of olfactory training with COT for weeks and all the treatment groups showed significant olfactory improvement after olfactory training (Qiao et al., 2020; Saatci et al., 2020). A study by Qiao et al. compared four different odors with COT twice daily for 6 months, and there was no significant difference in TDI improvements between the two groups (Qiao et al., 2020). Another study by Saatci et al. utilized an olfactory training ball for 12 weeks and patients receiving olfactory training ball exhibited significantly higher TDI scores than patients treated with COT (Saatci et al., 2020).

Another prospective, randomized, controlled clinical trial by Altundag et al. compared the effect of modified olfactory training (three sets of four different odors sequentially), COT, and no intervention in patients with PVOD (Altundag et al., 2015). Both the modified olfactory training and COT groups reached better scores than controls in terms of odor discrimination and odor identification. Besides, changing the types of odors periodically during olfactory training can enhance the likelihood of success of this olfactory therapy.

Another two prospective studies explored the effect of different odor concentrations and molecular weight odorants on the olfactory function in patients with PVOD (Damm et al., 2014; Poletti et al., 2017). An RCT evaluated heavy molecular weight odorants, followed by more than $150 \mathrm{~g} / \mathrm{mol}$ four times per day compared with light molecular weight odorants (Poletti et al., 2017). Heavy-weight molecules were associated with a larger improvement in threshold score at 5 months. Except for the threshold, there were no differences between light molecular weight odorants and heavy molecular weight odorants. Damm et al. performed different concentrations of odorants treating patients in PVOD and follow-up was 18 and 36 weeks (Damm et al., 2014). The use of odors at higher concentrations was more beneficial to PVOD than low concentrations of odorants within 12 months. At 18 weeks, $25.7 \%$ of the high-training group enhanced their olfactory function and achieved MCID. However, only $14.9 \%$ of the low-training group reported MCID. In either the high $(45.8 \%)$ or the low group (30.8\%), more patients had improvement at 36 weeks. The rate of olfactory recovery (defined as an increased $\geq 6$ in TDI score) in all studies referred to modified olfactory training increased separately around 50\% (51, 25.7, 45, 48.8, 50.9\%) (Figure 3). There was no significant difference in the recovery rate with prolonged treatment.

In summary, a recommendation supports the use of modified olfactory training for patients with PVOD. On the other hand, they are more helpful for the recovery of olfactory dysfunction on an earlier and prolonged start.

\section{Combination of Classic Olfactory Training and Steroid Treatment}

Five trials studied combined therapy of olfactory training and steroid vs. the control group (Table 4) (Fleiner et al., 2012; Nguyen and Patel, 2018; Abdelalim et al., 2021; Kasiri et al., 2021; Le Bon et al., 2021). The control group used COT only and the experimental group used COT and steroids. The treatment details involved exposure to four odors twice daily and budesonide $0.5 \mathrm{mg}$ twice daily for 4 or 8 months; $57.1 \%$ of patients receiving a combination of COT and topical steroids achieved an increase in TDI score $\geq 6$ and a combination of COT and topical steroids could enhance the efficacy of COT (Fleiner et al., 2012). Another study by Nguyen and Patel examined the effect of adding budesonide irrigation to olfactory training on patients with olfactory loss (Nguyen and Patel, 2018); $42.6 \%$ of patients with PVOD had a clinically significant change (defined as $a \geq 5$ increase in UPSIT scores). Abdelalim and Kasiri investigated the efficiency of mometasone nasal spray combination with COT in COVID-19 patients (Abdelalim et al., 2021; Kasiri et al., 2021). The recovery of olfactory dysfunction in the control group was $62 \%$ higher than $52 \%$ in the COT and nasal steroids group. One RCT evaluated the efficacy of COT and oral corticosteroids in patients with olfactory dysfunction secondary to COVID-19 (Le Bon et al., 2021). Patients in the COT and steroids group had improved their olfactory score by 7.7 points on average ( $p=0.007)$, compared with a 2.1-point increase in the COT group $(p=0.126)$.

In summary, olfactory training with steroids exhibits clinical significance in the improvement of the Sniffin' Sticks score. Although some studies showed there were no differences between a combination of nasal spray and olfactory training and olfactory training only, the use of steroid irrigation and oral corticosteroids 
TABLE 3 | Summary of modified olfactory training studies included in the systematic review.

\begin{tabular}{|c|c|c|c|c|c|c|c|c|c|}
\hline References & Design & Patients & Intervention & $\begin{array}{l}\text { Treatment } \\
\text { details }\end{array}$ & $\begin{array}{l}\text { The time of } \\
\text { initiation of } \\
\text { therapy }\end{array}$ & $\begin{array}{l}\text { Follow- } \\
\text { up }\end{array}$ & Improvement & Conclusion & $\begin{array}{l}\text { Level of } \\
\text { evidence }\end{array}$ \\
\hline $\begin{array}{l}\text { Qiao et al. } \\
\text { (2020) }\end{array}$ & $\begin{array}{l}\text { Prospective, } \\
\text { randomized } \\
\text { non-blinded } \\
\text { controlled trial }\end{array}$ & $\begin{array}{l}\text { Control group }(n= \\
60) \text { vs. Test group } \\
(n=65) \\
\text { All PVOD }\end{array}$ & $\begin{array}{l}\text { (1) Classical } \\
\text { olfactory training } \\
\text { (2) Training } \\
\text { with four } \\
\text { different odors }\end{array}$ & $\begin{array}{l}\text { (1) Exposure to } \\
\text { four odors twice } \\
\text { daily } \\
\text { (2) Exposure to } \\
\text { four different odors } \\
\text { twice daily }\end{array}$ & $\begin{array}{l}1 \text { year after } \\
\text { clinical onset }\end{array}$ & $\begin{array}{l}24 \\
\text { weeks }\end{array}$ & $\begin{array}{l}\text { An increase in Sniffin' } \\
\text { Sticks score } \geq 6 \\
\text { Control: } 41.54 \% \\
\text { Test: } 41.67 \% \\
\text { Control group } \\
\text { Threshold: } 6.8 \text { to } 6.9 \\
\text { Discrimination: } 7.2 \text { to } \\
9.5 \\
\text { Identification: } 2.9 \text { to } 6.1 \\
\text { The mean TDI score: } \\
16.8 \text { to } 22.5 \text { ( } p<0.05 \text { ) } \\
\text { Test group } \\
\text { Threshold: } 6.5 \text { to } 6.6 \\
\text { Discrimination: } 7.1 \text { to } \\
9.7 \\
\text { Identification: } 2.8 \text { to } 6.4 \\
\text { The mean TDI score: } \\
16.3 \text { to } 22.9(p<0.05 \text { ) }\end{array}$ & $\begin{array}{l}\text { In patients with PVOD, } \\
\text { there was no significant } \\
\text { difference in Sniffin' } \\
\text { Sticks score } \\
\text { improvements between } \\
\text { combinations. } \\
\text { The prolonged and } \\
\text { earlier start of olfactory } \\
\text { training would be } \\
\text { helpful for the recovery } \\
\text { of olfactory functions. }\end{array}$ & $2 \mathrm{~B}$ \\
\hline $\begin{array}{l}\text { Saatci et al. } \\
(2020)\end{array}$ & $\begin{array}{l}\text { Prospective, } \\
\text { randomized } \\
\text { non-blinded } \\
\text { controlled trial }\end{array}$ & $\begin{array}{l}\text { COT }(n=60) \text { vs. } \\
\text { OTB }(n=60) \\
\text { All PVOD }\end{array}$ & $\begin{array}{l}\text { (1) Classical } \\
\text { olfactory training } \\
\text { (2) Olfactory } \\
\text { training ball }\end{array}$ & $\begin{array}{l}\text { (1) Exposure to } \\
\text { four odors twice } \\
\text { daily } \\
\text { (2) Exposure to } \\
\text { four odors in a } \\
\text { sphere-shaped } \\
\text { ball twice daily }\end{array}$ & $\begin{array}{l}10 \text { years after } \\
\text { clinical onset }\end{array}$ & $\begin{array}{l}12 \\
\text { weeks }\end{array}$ & $\begin{array}{l}\text { An increase in Sniffin' } \\
\text { Sticks score } \geq 5.5 \\
\text { COT: } 30 \% \\
\text { OTB: } 70 \% \\
\text { COT group } \\
\text { Threshold: } 2.8 \text { to } 2.9 \\
\text { Discrimination: } 6.5 \text { to } \\
7.6 \\
\text { Identification: } 7.0 \text { to } 9.3 \\
\text { The mean TDI score: } \\
16.2 \text { to } 19.9 \text { ( } p< \\
\text { 0.001) } \\
\text { OTB group } \\
\text { Threshold: } 2.7 \text { to } 3.1 \\
\text { Discrimination: } 6.6 \text { to } \\
9.1 \\
\text { Identification: } 6.7 \text { to } 9.8 \\
\text { The mean TDI score: } \\
\text { 16.1 to } 22.1 \text { ( } p \\
<0.001 \text { ) }\end{array}$ & $\begin{array}{l}\text { Patients undergoing } \\
\text { OTB exhibited } \\
\text { significantly higher } \\
\text { scores than patients } \\
\text { who were treated with } \\
\text { OT. }\end{array}$ & $2 \mathrm{~B}$ \\
\hline
\end{tabular}


TABLE 3 | Continued

\begin{tabular}{|c|c|c|c|c|c|c|c|c|c|}
\hline References & Design & Patients & Intervention & $\begin{array}{l}\text { Treatment } \\
\text { details }\end{array}$ & $\begin{array}{l}\text { The time of } \\
\text { initiation of } \\
\text { therapy }\end{array}$ & $\begin{array}{l}\text { Follow- } \\
\text { up }\end{array}$ & Improvement & Conclusion & $\begin{array}{l}\text { Level of } \\
\text { evidence }\end{array}$ \\
\hline $\begin{array}{l}\text { Altundag } \\
\text { et al. (2015) }\end{array}$ & $\begin{array}{l}\text { Prospective, } \\
\text { randomized, } \\
\text { controlled } \\
\text { clinical trial }\end{array}$ & $\begin{array}{l}\text { MOT }(n=37) \text { vs. } \\
\text { COT }(n=33) \text { vs. } \\
\text { Control group }(n= \\
\text { 15) } \\
\text { All PVOD }\end{array}$ & $\begin{array}{l}\text { (1) Modified } \\
\text { olfactory training } \\
\text { (2) Classical } \\
\text { olfactory training } \\
\text { (3) } \\
\text { Control group }\end{array}$ & $\begin{array}{l}\text { (1) Exposure to } \\
\text { four odors twice } \\
\text { daily for } 36 \text { weeks } \\
\text { (2) Exposure to } \\
\text { four odors twice } \\
\text { daily for } 12 \text { weeks, } \\
\text { followed by four } \\
\text { different odors for } \\
12 \text { weeks, } \\
\text { followed by four } \\
\text { different odors for } \\
12 \text { weeks } \\
\text { (3) No treatment }\end{array}$ & $\begin{array}{l}7 \text { months } \\
\text { after clinical } \\
\text { onset }\end{array}$ & $\begin{array}{l}12,24, \\
\text { and } 36 \\
\text { weeks }\end{array}$ & $\begin{array}{l}\text { An increase in Sniffin' } \\
\text { Sticks score } \geq 6 \\
\text { Week } 36 \\
\text { MOT: } 56 \% \\
\text { COT: } 46 \% \\
\text { MOT group } \\
\text { Threshold: } 2.4 \text { to } 2.8 \\
\text { Discrimination: } 7.7 \text { to } \\
10.9 \\
\text { Identification: } 8 \text { to } 12.6 \\
\text { The mean TDI score: } \\
18.1 \text { to } 26.3 \text { ( } p< \\
0.001 \text { ) } \\
\text { COT group } \\
\text { Threshold: } 2.5 \text { to } 2.7 \\
\text { Discrimination: } 7.5 \text { to } \\
10.1 \\
\text { Identification: } 8.2 \text { to } \\
11.5 \\
\text { The mean TDI score: } \\
18.2 \text { to } 24.3 \text { ( } p< \\
0.001 \text { ) } \\
\text { Control group } \\
\text { Threshold: } 2.5 \text { to } 2.6 \\
\text { Discrimination: } 7.4 \text { to } \\
8.1 \\
\text { Identification: } 8.1 \text { to } 8.9 \\
\text { The mean TDI score: } \\
18 \text { to } 19.7 \text { ( } p \leq 0.05 \text { ) }\end{array}$ & $\begin{array}{l}\text { Changing the types of } \\
\text { odors periodically } \\
\text { during OT can enhance } \\
\text { the likelihood of } \\
\text { success of this } \\
\text { olfactory therapy. }\end{array}$ & $1 \mathrm{~B}$ \\
\hline
\end{tabular}


TABLE 3 | Continued

\begin{tabular}{|c|c|c|c|c|c|c|c|c|c|}
\hline References & Design & Patients & Intervention & $\begin{array}{l}\text { Treatment } \\
\text { details }\end{array}$ & $\begin{array}{l}\text { The time of } \\
\text { initiation of } \\
\text { therapy }\end{array}$ & $\begin{array}{l}\text { Follow- } \\
\text { up }\end{array}$ & Improvement & Conclusion & $\begin{array}{l}\text { Level of } \\
\text { evidence }\end{array}$ \\
\hline $\begin{array}{l}\text { Poletti et al. } \\
\text { (2017) }\end{array}$ & $\begin{array}{l}\text { Prospective, } \\
\text { pseudorandomized } \\
\text { trial }\end{array}$ & $\begin{array}{l}\text { Light molecular } \\
\text { d weight OT ( } n=37) \\
\text { vs. Heavy } \\
\text { molecular weight } \\
\text { OT }(n=33) \\
\text { PVOD: } 70 / 96 \\
\text { Post- } \\
\text { traumatic: } 26 / 96\end{array}$ & $\begin{array}{l}\text { (1) Training } \\
\text { with light } \\
\text { molecular } \\
\text { weight odorants } \\
\text { (2) Training } \\
\text { with heavy } \\
\text { molecular } \\
\text { weight odorants }\end{array}$ & $\begin{array}{l}\text { Exposure to three } \\
\text { odors twice in the } \\
\text { morning and twice } \\
\text { in the evening } \\
\text { (1) Light molecular } \\
\text { weight odorants } \\
<150 \mathrm{~g} / \mathrm{mol} \\
\text { (2) Heavy } \\
\text { molecular weight } \\
\text { odorants }>150 \\
\mathrm{~g} / \mathrm{mol}\end{array}$ & - & $\begin{array}{l}20 \\
\text { weeks }\end{array}$ & $\begin{array}{l}\text { An increase in Sniffin' } \\
\text { Sticks score } \geq 5.5 \\
\text { All PVOD: } 45 \% \\
\text { Light molecular group } \\
\text { Threshold: } 2.8 \text { to } 3.9 \\
\text { Discrimination: } 8.5 \text { to } \\
10.5 \\
\text { Identification: } 7.4 \text { to } 8 \\
\text { The mean TDI score: } \\
18.6 \text { to } 22.3 \text { ( } p= \\
0.021 \text { ) } \\
\text { Heavy molecular group } \\
\text { Threshold: } 1.9 \text { to } 4.5 \\
\text { Discrimination: } 9.1 \text { to } \\
11.1 \\
\text { Identification: } 6.9 \text { to } 7.5 \\
\text { The mean TDI score: } \\
17.7 \text { to } 23 \text { ( } p<0.001 \text { ) }\end{array}$ & $\begin{array}{l}\text { In patients with PVOD, } \\
\text { training with } \\
\text { heavy-weight } \\
\text { molecules produced an } \\
\text { improved threshold } \\
\text { compared with } \\
\text { light-weight molecules; } \\
\text { except for threshold } \\
\text { scores, there were no } \\
\text { differences between } \\
\text { LWM and HWM. }\end{array}$ & 4 \\
\hline $\begin{array}{l}\text { Damm et al. } \\
\text { (2014) }\end{array}$ & $\begin{array}{l}\text { Randomized, } \\
\text { single-blind, } \\
\text { controlled } \\
\text { crossover } \\
\text { clinical trial }\end{array}$ & $\begin{array}{l}\text { High-training } \\
\text { group }(n=70) \text { vs. } \\
\text { Low-training group } \\
(n=74) \\
\text { All PVOD }\end{array}$ & $\begin{array}{l}\text { (1) Training } \\
\text { with high } \\
\text { concentration } \\
\text { odorants (2) } \\
\text { Training with } \\
\text { low } \\
\text { concentration } \\
\text { odorants (3) } \\
\text { Crossover in } \\
\text { treatment } \\
\text { regimen at } \\
18 \text { weeks }\end{array}$ & $\begin{array}{l}\text { (1) Exposure to } \\
\text { four odors twice } \\
\text { daily } \\
\text { (2) Exposure to } \\
\text { four odors twice } \\
\text { daily of } \\
\text { concentration at } \\
\text { the 10th percentile } \\
\text { of the threshold of } \\
\text { healthy volunteers }\end{array}$ & $\begin{array}{l}10.5 \text { months } \\
\text { after clinical } \\
\text { onset }\end{array}$ & $\begin{array}{l}18 \text { and } \\
36 \\
\text { weeks }\end{array}$ & $\begin{array}{l}\text { An increase in Sniffin' } \\
\text { Sticks score } \geq 6 \\
\text { Week } 36: \\
\text { High: } 45.8 \% \\
\text { Low: } 30.8 \% \\
\text { Low-high training } \\
\text { group } \\
\text { Threshold: } 2.6 \text { to } 3.42 \\
\text { Discrimination: } 8 \text { to } 10 \\
\text { Identification: } 7.54 \text { to } \\
8.7 \\
\text { The mean TDI score: } \\
18.2 \text { to } 22.1 \text { ( } p< \\
0.001) \\
\text { High-low training group } \\
\text { Threshold: } 2.8 \text { to } 3.5 \\
\text { Discrimination: } 7.9 \text { to } \\
9.9 \\
\text { Identification: } 7.15 \text { to } \\
8.9 \\
\text { The mean TDI score: } \\
17.9 \text { to } 22.3 \text { (p } \\
<0.001)\end{array}$ & $\begin{array}{l}\text { The use of odors at } \\
\text { higher concentrations } \\
\text { is beneficial to PVOD; it } \\
\text { seems particularly } \\
\text { useful in patients who } \\
\text { start OT within } 12 \\
\text { months after the onset } \\
\text { of the disorder ( } p= \\
\text { 0.03). }\end{array}$ & $2 \mathrm{~B}$ \\
\hline
\end{tabular}

PVOD, postviral olfactory dysfunction; OT, olfactory training; COT, classic olfactory training; MOT, modified olfactory training; LWM, light molecular weight odorants; HWM, heavy molecular weight odorants; OTB, olfactory training ball. 


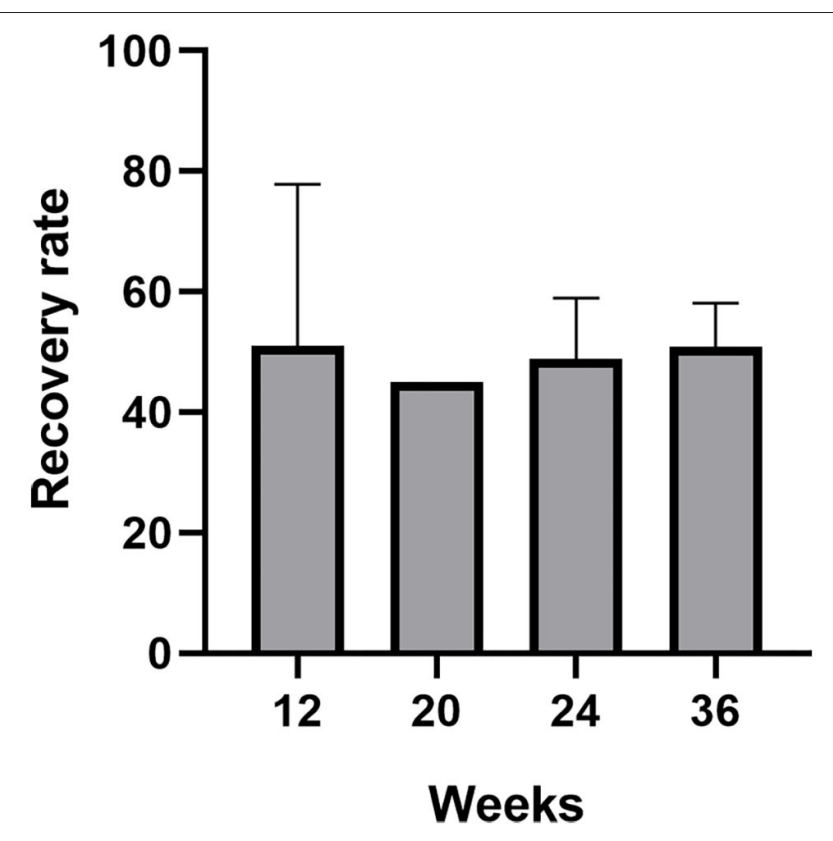

FIGURE 3 | The recovery rate (defined as an increased $\geq 6$ in TDI score) of patients with PVOD who used modified olfactory training with different treatment duration $(12,20,24$, and 36 weeks).

in addition to COT could be beneficial in accelerating the recovery of PVOD. A combination of steroids and olfactory training is more efficient than olfactory training only in managing olfactory dysfunction from PVOD.

\section{DISCUSSION}

This is the first systematic review summarizing the evidence for steroids, olfactory training, or both interventions in the treatment of PVOD and revealed the improvement and optimization of treatment modalities. For steroid treatment, direct injection of steroid or nasal steroid spray into the olfactory cleft significantly improved the olfactory function in patients with PVOD and nasal steroid spray alone is not recommended (Heilmann et al., 2004; Fukazawa, 2005; Fleiner and Goktas, 2011). These studies indicated that direct alleviation of the lesions in the olfactory cleft facilitated the olfactory improvement in patients with PVOD. It has been reported that nasal steroid sprays deliver medication to the restricted areas including the anterior and inferior parts of the nasal cavity and the deposition of steroids in the superior and posterior of the nasal passages is relatively limited (Djupesland and Skretting, 2012; Lam et al., 2013; Emanuel et al., 2014). That might explain why local steroids direct into the olfactory cleft demonstrated exact treatment effect in patients with PVOD. Similarly, head positions including Kaiteki and Mygind positions delivered the nasal drops effectively to the olfactory epithelium, and further studies should evaluate the effect of nasal steroid drops with these two head positions in patients with PVOD (Mori et al., 2016; Milk et al., 2021). When comparing the uses of steroids in patients with PVOD, two studies showed the TDI scores improved from 14.39 to $18.86,15.2$ to 16.9 in the systemic steroids group, while the TDI scores even decreased in the nasal steroids group (Jaeschke et al., 1989; Schriever et al., 2012). It should be pointed out that current evidence supporting systemic steroids over nasal steroids spray in patients with PVOD is limited and more studies are needed (Heilmann et al., 2004; Schriever et al., 2012).

We next systematically reviewed the efficiency of different olfactory training modalities in patients with PVOD from the perspective of olfactory recovery rate. Recent meta-analyses found a beneficial effect from olfactory training on a range of etiologies including PVOD for olfactory dysfunction, although characterized by a high level of heterogeneity among included studies (Pekala et al., 2016). A consensus about the treatment of PVOD suggested that olfactory training was an overwhelming recommendation for olfactory therapy in patients with PVOD (Pekala et al., 2016; Sorokowska et al., 2017; Kattar et al., 2020; Addison et al., 2021). Although there is growing evidence supporting the efficiency of COT in patients with PVOD, the exact effect of modification of the COT including treatment duration, various odorants, olfactory training device (olfactory training ball), changing the types of odors periodically, different molecular odorants, and different concentrations of odorants on patients with PVOD is not systematically reviewed.

This systematic review firstly showed that more patients with PVOD would achieve MCID after long-term COT (16 weeks, $60.6 \%$; 32 weeks, $79 \%$; 56 weeks, $71 \%$ ) than those after short-term COT (12 weeks, 37.05\%) (Figure 2) (Hummel et al., 2009; Konstantinidis et al., 2013, 2016; Geißler et al., 2014; Gellrich et al., 2018). It can be inferred that long-term olfactory training provided sustainable improvement of at least 56 weeks and the training effect consistently modulated the olfactory system. Recent fMRI studies on patients with PVOD showed that olfactory training reorganized functional connectivity networks, especially within the visual cortex (Kollndorfer et al., 2014; Jiramongkolchai et al., 2021). An extended period of odor exposure maintained the olfactory training effect at a sustainable high level. However, the mechanism accounting for the difference between short-term and long-term effects is still unknown.

As for the types of odorant, MOT with four different odors (essential balm, vinegar, alcohol, and rose perfume) was not superior to COT regarding the difference in TDI improvements (Qiao et al., 2020). This study demonstrated that different types of olfactory agents which irritated the olfactory system and nasal trigeminal system functioned similarly in improving olfaction. A new olfactory training device called olfactory training ball increased adherence to the training process, which was associated with better olfactory outcomes than COT (Saatci et al., 2020). Interestingly, changing the odors with prolonged olfactory training duration ( $>12$ weeks) would enhance the likelihood of success of this therapy (Altundag et al., 2015). Furthermore, continuing olfactory training with four different odors after 12 and 24 weeks produced better results in terms of odor discrimination and odor identification scores as compared with COT throughout the entire study. Previous studies showed that it was odor discrimination and odor identification and not odor thresholds that correlated 
TABLE 4 | Summary of combination with olfactory training and steroid studies included in the systematic review.

\begin{tabular}{|c|c|c|c|c|c|c|c|c|c|}
\hline References & Design & Patients & Intervention & $\begin{array}{l}\text { Treatment } \\
\text { details }\end{array}$ & $\begin{array}{l}\text { The time of } \\
\text { initiation of } \\
\text { therapy }\end{array}$ & $\begin{array}{l}\text { Follow- } \\
\text { up }\end{array}$ & Improvement & Conclusion & $\begin{array}{l}\text { Level of } \\
\text { evidence }\end{array}$ \\
\hline $\begin{array}{l}\text { Fleiner et al. } \\
\text { (2012) }\end{array}$ & $\begin{array}{l}\text { Retrospective } \\
\text { case series }\end{array}$ & $\begin{array}{l}\text { COT }(n=9) \text { vs. } \\
\text { COT }+ \text { steroids } \\
\text { group }(n=7) \\
\text { PVOD: } 16 / 46 \\
\text { Post-traumatic: } \\
7 / 46 \\
\text { Sinonasal: } 15 / 46 \\
\text { Idiopathic: } 8 / 46\end{array}$ & $\begin{array}{l}\text { (1) Classic } \\
\text { olfactory } \\
\text { training only } \\
\text { (2) Classic } \\
\text { olfactory } \\
\text { training }+ \\
\text { topical } \\
\text { corticosteroids }\end{array}$ & $\begin{array}{l}\text { (1) Exposure to } \\
\text { four odors twice } \\
\text { daily } \\
\text { (2) Topical } \\
\text { corticosteroid } \\
\text { treatment not } \\
\text { specified }\end{array}$ & $\begin{array}{l}21 \text { months } \\
\text { after clinical } \\
\text { onset }\end{array}$ & $\begin{array}{l}16 \text { and } \\
32 \\
\text { weeks }\end{array}$ & $\begin{array}{l}\text { An increase in Sniffin' } \\
\text { Sticks score } \geq 6 \\
\text { Month } 4 \\
\text { COT: } 11.1 \% \\
\text { COT + steroids: } 14.3 \% \\
\text { Month } 8 \\
\text { COT: } 11.1 \% \\
\text { COT + steroids: } 57.1 \%\end{array}$ & $\begin{array}{l}\text { In all PVOD patients, } \\
\text { the improvement of } \\
\text { Sniffin' Sticks score } \\
\text { caused by COT } \\
\text { exhibited little clinical } \\
\text { significance; a } \\
\text { combination of COT } \\
\text { and steroids could } \\
\text { enhance the efficacy of } \\
\text { COT }\end{array}$ & 4 \\
\hline $\begin{array}{l}\text { Nguyen and } \\
\text { Patel (2018) }\end{array}$ & $\begin{array}{l}\text { Randomized } \\
\text { controlled trial }\end{array}$ & $\begin{array}{l}\text { Control group ( } n= \\
\text { 30) vs. } \\
\text { Budesonide } \\
\text { irrigation group ( } n \\
=32 \text { ) } \\
\text { PVOD: 62/133 } \\
\text { Idiopathic: } 46 / 133 \\
\text { Medication- } \\
\text { related: 6/133 } \\
\text { Post-traumatic: } \\
\text { 16/133 } \\
\text { Environmental } \\
\text { exposure: } 3 / 133\end{array}$ & $\begin{array}{l}\text { (1) Classic } \\
\text { olfactory } \\
\text { training }+ \\
\text { saline } \\
\text { irrigation (2) } \\
\text { Classic } \\
\text { olfactory } \\
\text { training }+ \\
\text { budesonide } \\
\text { irrigation }\end{array}$ & $\begin{array}{l}\text { (1) Exposure to } \\
\text { four odors twice } \\
\text { daily and saline } \\
\text { irrigations twice } \\
\text { daily } \\
\text { (2) Exposure to } \\
\text { four odors twice } \\
\text { daily and } \\
\text { budesonide } \\
0.5 \mathrm{mg} \text { twice daily }\end{array}$ & $\begin{array}{l}1-2 \text { years } \\
\text { after clinical } \\
\text { onset }\end{array}$ & $\begin{array}{l}24 \\
\text { weeks }\end{array}$ & $\begin{array}{l}\text { An increase in UPSIT } \\
\text { score } \geq 5 \\
\text { All patients } \\
\text { Control group: } 26.9 \% \\
\text { Budesonide irrigation } \\
\text { group: } 43.9 \% \\
\text { All PVOD: } 42.6 \%\end{array}$ & $\begin{array}{l}\text { Olfactory training with } \\
\text { budesonide irrigation } \\
\text { significantly improves } \\
\text { olfaction compared } \\
\text { with olfactory training } \\
\text { using saline irrigation } \\
\text { alone }\end{array}$ & $1 \mathrm{~B}$ \\
\hline $\begin{array}{l}\text { Abdelalim } \\
\text { et al. (2021) }\end{array}$ & $\begin{array}{l}\text { Prospective, } \\
\text { randomized } \\
\text { controlled trial }\end{array}$ & $\begin{array}{l}\text { COT }(n=50) \text { vs. } \\
\text { COT }+ \text { steroids } \\
\text { group }(n=50) \\
\text { All COVID-19 }\end{array}$ & $\begin{array}{l}\text { (1) Classic } \\
\text { olfactory } \\
\text { training only } \\
\text { (2) Classic } \\
\text { olfactory } \\
\text { training }+ \\
\text { mometasone } \\
\text { nasal spray }\end{array}$ & $\begin{array}{l}\text { (1) Exposure to } \\
\text { four odors twice } \\
\text { daily } \\
\text { (2) Exposure to } \\
\text { four odors twice } \\
\text { daily and } \\
\text { mometasone two } \\
\text { puffs/nasal cavity } \\
\text { once daily }\end{array}$ & $\begin{array}{l}12 \text { days after } \\
\text { clinical onset }\end{array}$ & 3 weeks & $\begin{array}{l}\text { VAS score improved to } \\
10 \\
\text { COT: } 62 \% \\
\text { COT + steroids: } 52 \%\end{array}$ & $\begin{array}{l}\text { This topical } \\
\text { corticosteroid nasal } \\
\text { spray shows no } \\
\text { superiority in the } \\
\text { treatment of } \\
\text { post-COVID-19 } \\
\text { anosmia over the } \\
\text { olfactory training }\end{array}$ & $1 \mathrm{~B}$ \\
\hline $\begin{array}{l}\text { Kasiri et al. } \\
\text { (2021) }\end{array}$ & $\begin{array}{l}\text { Prospective, } \\
\text { randomized } \\
\text { controlled trial }\end{array}$ & $\begin{array}{l}\text { COT + placebo } \\
\text { group }(n=38) \text { vs. } \\
\text { COT + steroids } \\
\text { group }(n=39) \\
\text { All COVID-19 }\end{array}$ & $\begin{array}{l}\text { (1) Classic } \\
\text { olfactory } \\
\text { training }+ \\
\text { saline spray } \\
\text { (2) Classic } \\
\text { olfactory } \\
\text { training }+ \\
\text { mometasone } \\
\text { nasal spray }\end{array}$ & $\begin{array}{l}\text { (1) Exposure to } \\
\text { four odors twice } \\
\text { Daily and saline } \\
\text { two puffs/nasal } \\
\text { cavity twice daily } \\
\text { (2) Exposure to } \\
\text { four odors twice } \\
\text { daily and } \\
\text { mometasone two } \\
\text { puffs/nasal cavity } \\
\text { twice daily }\end{array}$ & $\begin{array}{l}2 \text { weeks after } \\
\text { clinical onset }\end{array}$ & 4 weeks & $\begin{array}{l}\text { The changes in VAS } \\
\text { score, mean (SD), the } \\
\text { rate of normal smell } \\
\text { after therapy } \\
\text { COT + placebo: } 5.7 \\
(1.6), 48.7 \% \\
\text { COT + steroids: } 5.2 \\
(2.3), 21.1 \% \text { ( } p= \\
0.329)\end{array}$ & $\begin{array}{l}\text { Compared with } \\
\text { olfactory training, } \\
\text { mometasone furoate } \\
\text { nasal spray } \\
\text { combination with } \\
\text { olfactory training } \\
\text { showed a higher } \\
\text { improvement in severe } \\
\text { chronic anosmia by } \\
\text { COVID-19 }\end{array}$ & $1 \mathrm{~B}$ \\
\hline
\end{tabular}




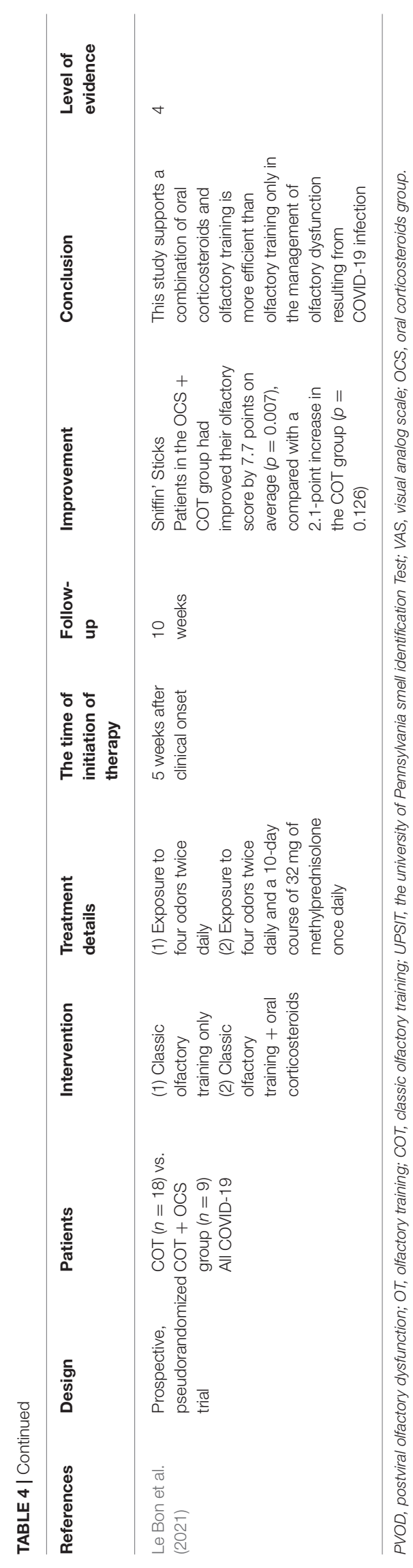

significantly with tests of executive function and semantic memory which is highly associated with central processing and cognitive function (Nasreddine et al., 2005; Hedner et al., 2010). We speculated that changing the odors with prolonged olfactory training produced cognitive improvement, which further leads to improved olfactory perception.

As for the different molecular weight odorant and odor concentrations, heavy-weight molecules were associated with a larger improvement in threshold score, and more patients with PVOD would achieve MCID in the high-concentration training group than that in the low-concentration training group (Damm et al., 2014; Poletti et al., 2017). A recent meta-analysis showed that it was the odor discrimination and odor identification but not odor thresholds that improved after olfactory training among patients with olfactory loss due to varied etiologies (Pekala et al., 2016). It seems that changes in molecular weight odorant during olfactory training would facilitate the improvement of odor thresholds, which provided a new strategy to comprehensively improve olfactory function in patients with PVOD.

We also summarized the olfactory recovery rates (defined as an increased $\geq 6$ in TDI score) in patients with different MOT and also found that the recovery rate (50\% on average) did not significantly change among prolonged treatment duration (at weeks 12, 20, 24, and 36) (Figure 3) (Damm et al., 2014; Altundag et al., 2015; Poletti et al., 2017; Qiao et al., 2020; Saatci et al., 2020). Currently, studies with a treatment duration of MOT $>36$ weeks in patients with PVOD are still lacking. Based on the above evidence, we speculated that the modification of COT did not change the percentage of patients achieving MCID. Moreover, further studies of direct comparison between various MOT and COT with treatment duration $>36$ weeks are warranted.

A thorough discussion on whether a combination of steroids and olfactory training is better than monotherapy has not been reported. It is imperative to confirm the efficacy of steroids and olfactory training on patients with PVOD. Fleiner et al. showed $57.1 \%$ of patients receiving a combination of COT and topical steroids achieved an increase in TDI score $\geq 6$ and a combination of COT and topical steroids could enhance the efficacy of COT (Fleiner et al., 2012). Similarly, an RCT by Nguyen and Patel showed that using budesonide irrigation with COT was superior to COT alone and $42.6 \%$ of patients with PVOD had a clinically significant change (defined as a $\geq 5$ increase in UPSIT scores) (Nguyen and Patel, 2018). It can be inferred that the addition of steroids including nasal steroid spray or steroid irrigation to COT could significantly improve the efficiency of COT within 8 months. Presumably, local steroids could suppress inflammation within sinonasal cavities that caused anosmia and promote proper neuronal regeneration at the same time to enhance the effect of COT (Nguyen and Patel, 2018). During the COVID-19 pandemic, exploring the treatment of patients with olfactory dysfunction was important. This systematic review also compared combined olfactory training and steroids with olfactory training alone in patients with post-COVID-19 anosmia. Consensus guidelines had identified the appropriateness of olfactory training for all patients with olfactory dysfunction of more than 2 weeks duration, and topical and systemic steroids may be considered based on the use of 
olfactory training (Hopkins et al., 2021). Two RCTs showed olfactory improvement in treatment with a combination of nasal spray and olfactory training (Abdelalim et al., 2021; Kasiri et al., 2021). Furthermore, a higher improvement in severe chronic anosmia by COVID-19 was observed. Interestingly, another study by Le et al. showed that a combination of COT and oral steroids for 10 weeks was more effective than olfactory training only in patients with COVID-19 (Le Bon et al., 2021). However, considering the systemic side effects, it is not recommended to use oral corticosteroids more than 2 weeks with persistent olfactory dysfunction after COVID-19 (Hopkins et al., 2021). Given the available evidence, large randomized controlled trials are needed to verify the exact effect of steroids with COT in patients with PVOD.

It should be pointed out that there was a strong association between the time of initiation of therapy and the recovery rate after treatment in patients with PVOD, with more improvement the earlier the initiation of therapy including steroids and olfactory training. It can be inferred that patients would benefit more when the time of initiation of therapy starts earlier. It has been proposed that steroids potentiated the effects of olfactory training by dampening any inflammation that could be causing or exacerbating olfactory loss (Nguyen and Patel, 2018).

The limitations of this study include a small number of randomized controlled trials and a lack of enough control groups. The lack of sufficient study and quantifiable data in the meta-analysis limits results and evidence. Some studies used no interventions and other used placebos for the control group. RCTs are needed to verify the effect of steroid, olfactory training, or a combination of both in patients with PVOD.

\section{CONCLUSION}

With the accumulation of studies exploring the effects of steroids or olfactory training in patients with PVOD, evidence focused on the improvement and optimization of these treatment modalities is expanding. Direct injection of steroid or nasal spray into the olfactory cleft proved to be a promising therapy for patients

\section{REFERENCES}

Abdelalim, A. A., Mohamady, A. A., Elsayed, R. A., Elawady, M. A., and Ghallab, A. F. (2021). Corticosteroid nasal spray for recovery of smell sensation in COVID19 patients: a randomized controlled trial. Am. J. Otolaryngol. 42:102884. doi: 10.1016/j.amjoto.2020.102884

Addison, A. B., Wong, B., Ahmed, T., Macchi, A., Konstantinidis, I., Huart, C., et al. (2021). Clinical olfactory working group consensus statement on the treatment of post-infectious olfactory dysfunction. J. Allergy Clin. Immunol. 147, 1704-1719. doi: 10.1016/j.jaci.2020.12.641

Altundag, A., Cayonu, M., Kayabasoglu, G., Salihoglu, M., Tekeli, H., Saglam, O., et al. (2015). Modified olfactory training in patients with postinfectious olfactory loss. Laryngoscope 125, 1763-1766. doi: 10.1002/lary. 25245

Burns, P. B., Rohrich, R. J., and Chung, K. C. (2011). The levels of evidence and their role in evidence-based medicine. Plast. Reconstr. Surg. 128, 305-310. doi: 10.1097/PRS.0b013e318219c171

Damm, M., Pikart, L. K., Reimann, H., Burkert, S., Göktas, Ö., Haxel, B., et al. (2014). Olfactory training is helpful in postinfectious olfactory loss: with PVOD. Patients with PVOD would benefit more from longterm COT ( $>12$ weeks). Factors including treatment duration, various odorants, olfactory training devices, changing the types of odors periodically, different molecular odorants, and different concentrations of odorants tended to increase the efficiency of MOT. Furthermore, a combination of COT and topical steroids can significantly improve olfactory function in patients with PVOD. More additional randomized controlled trials related to combined steroids irrigation or spray with COT are needed.

\section{DATA AVAILABILITY STATEMENT}

The original contributions presented in the study are included in the article/supplementary material, further inquiries can be directed to the corresponding author/s.

\section{AUTHOR CONTRIBUTIONS}

All authors have made substantial contributions to the conception, analysis, and interpretation of data in this article, approved the submitted version, and agreed to be personally accountable for our contributions and to ensure that questions related to the accuracy or integrity of any part of the work, even ones in which we are not personally involved, are appropriately investigated and resolved, and the resolution documented in the literature.

\section{FUNDING}

DW is supported by grants from the Beijing Hospitals Authority Youth Program (QML20190617), Beijing Science and Technology Nova Program (Z201100006820086), Natural Science Foundation of China (82000954), and Beijing Hospitals Authority Clinical Medicine Development of Special Funding (XMLX202136). YW is supported by grants from Beijing Hospitals Authority's Mission Plan (SML20190601), Beijing Scholars Program (No. 051), and National Key R\&D Program of China (2019YFE0116000). a randomized, controlled, multicenter study. Laryngoscope 124, 826-831. doi: 10.1002/lary.24340

Djupesland, P. G., and Skretting, A. (2012). Nasal deposition and clearance in man: comparison of a bidirectional powder device and a traditional liquid spray pump. J. Aerosol Med. Pulm. Drug Deliv. 25, 280-289. doi: 10.1089/jamp.2011.0924

Emanuel, I. A., Blaiss, M. S., Meltzer, E. O., Evans, P., and Connor, A. (2014). Nasal deposition of ciclesonide nasal aerosol and mometasone aqueous nasal spray in allergic rhinitis patients. Am. J. Rhinol. Allergy 28, 117-121. doi: $10.2500 /$ ajra.2014.28.4026

Fleiner, F., and Goktas, O. (2011). Topical beclomethasone in the therapy of smelling disorders-a new application technique. Indian J. Otolaryngol. Head Neck Surg. 63, 5-9. doi: 10.1007/s12070-010-0063-z

Fleiner, F., Lau, L., and Göktas, Ö. (2012). Active olfactory training for the treatment of smelling disorders. Ear Nose Throat J. 91, 198-215. doi: $10.1177 / 014556131209100508$

Fukazawa, K. A. (2005). Local steroid injection method for olfactory loss due to upper respiratory infection. Chem. Senses 30, i212-i213. doi: 10.1093/chemse/bjh189 
Geißler, K., Reimann, H., Gudziol, H., Bitter, T., and Guntinas-Lichius, O. (2014). Olfactory training for patients with olfactory loss after upper respiratory tract infections. Eur. Arch. Otorhinolaryngol. 271, 1557-1562. doi: 10.1007/s00405-013-2747-y

Gellrich, J., Han, P., Manesse, C., Betz, A., Junghanns, A., Raue, C., et al. (2018). Brain volume changes in hyposmic patients before and after olfactory training. Laryngoscope; 128, 1531-1536. doi: 10.1002/lary.27045

Hedner, M., Larsson, M., Arnold, N., Zucco, G. M., and Hummel, T. (2010). Cognitive factors in odor detection, odor discrimination, and odor identification tasks. J. Clin. Exp. Neuropsychol. 32, 1062-1067. doi: $10.1080 / 13803391003683070$

Heilmann, S., Huettenbrink, K. B., and Hummel, T. (2004). Local and systemic administration of corticosteroids in the treatment of olfactory loss. Am. J. Rhinol. 18, 29-33. doi: 10.1177/194589240401800107

Hopkins, C., Alanin, M., Philpott, C., Harries, P., Whitcroft, K., Qureishi, A., et al. (2021). Management of new onset loss of sense of smell during the COVID-19 pandemic - BRS consensus guidelines. Clin. Otolaryngol. 46, 16-22. doi: 10.1111/coa.13636

Hummel, T., Rissom, K., Reden, J., Hähner, A., Weidenbecher, M., and Hüttenbrink, K. B. (2009). Effects of olfactory training in patients with olfactory loss. Laryngoscope 119, 496-499. doi: 10.1002/lary.20101

Hummel, T., Whitcroft, K. L., Andrews, P., Altundag, A., Cinghi, C., Costanzo, R. M., et al. (2017a). Position paper on olfactory dysfunction. Rhinol Suppl. 54, 1-30. doi: 10.4193/Rhino16.248

Hummel, T., Whitcroft, K. L., Rueter, G., and Haehner, A. (2017b). Intranasal vitamin A is beneficial in post-infectious olfactory loss. Eur. Arch. Otorhinolaryngol. 274, 2819-2825. doi: 10.1007/s00405-017-4576-x

Jaeschke, R., Singer, J., and Guyatt, G. H. (1989). Measurement of health status: ascertaining the minimal clinically important difference. Control Clin. Trials 10, 407-415. doi: 10.1016/0197-2456(89)90005-6

Jiang, R. S., Twu, C. W., and Liang, K. L. (2015). Medical treatment of traumatic anosmia. Otolaryngol. Head Neck Surg. 152, 954-958. doi: 10.1177/0194599815571272

Jiramongkolchai, P., Jones, M. S., Peterson, A., Lee, J. J., Liebendorfer, A., KlattCromwell, C. N., et al. (2021). Association of olfactory training with neural connectivity in adults with postviral olfactory dysfunction. JAMA Otolaryngol. Head Neck Surg. e210086. doi: 10.1001/jamaoto.2021.0086

Kasiri, H., Rouhani, N., Salehifar, E., Ghazaeian, M., and Fallah, S. (2021). Mometasone furoate nasal spray in the treatment of patients with COVID19 olfactory dysfunction: a randomized, double blind clinical trial. Int. Immunopharmacol. 98:107871. doi: 10.1016/j.intimp.2021.107871

Kattar, N., Do, T. M., Unis, G. D., Migneron, M. R., Thomas, A. J., and McCoul, E. D. (2020). Olfactory training for postviral olfactory dysfunction: systematic review and meta-analysis. Otolaryngol. Head Neck Surg. 164, 244-254. doi: 10.1177/0194599820943550

Kim, D. H., Kim, S. W., Hwang, S. H., Kim, B. G., Kang, J. M., Cho, J. H., et al. (2017). Prognosis of olfactory dysfunction according to etiology and timing of treatment. Otolaryngol. Head Neck Surg. 156, 371-377. doi: $10.1177 / 0194599816679952$

Kollndorfer, K., Kowalczyk, K., Hoche, E., Mueller, C. A., Pollak, M., Trattnig, S., et al. (2014). Recovery of olfactory function induces neuroplasticity effects in patients with smell loss. Neural Plast. 2014:140419. doi: 10.1155/2014/ 140419

Konstantinidis, I., Tsakiropoulou, E., Bekiaridou, P., Kazantzidou, C., and Constantinidis, J. (2013). Use of olfactory training in post-traumatic and post-infectious olfactory dysfunction. Laryngoscope 123, E85-E90. doi: $10.1002 /$ lary. 24390

Konstantinidis, I., Tsakiropoulou, E., and Constantinidis, J. (2016). Long term effects of olfactory training in patients with post-infectious olfactory loss. Rhinology 54, 170-175. doi: 10.4193/Rhino15.264

Lam, K., Tan, B., Lavin, J., Meen, E., and Conley, D. (2013). Comparison of nasal sprays and irrigations in the delivery of topical agents to the olfactory mucosa. Laryngoscope 123, 2950-2957. doi: 10.1002/lary. 24239

Le Bon, S. D., Konopnicki, D., Pisarski, N., Prunier, L., Lechien, J. R., and Horoi, M. (2021). Efficacy and safety of oral corticosteroids and olfactory training in the management of COVID-19-related loss of smell. Eur. Arch. Otorhinolaryngol. 278, 3113-3117. doi: 10.1007/s00405-020-06520-8
Milk, D. G., Khong, G. C., Çam, O. H., Alfaro-Iraheta, F., Tierney, C., Kassem, F., et al. (2021). A Comparison between Mygind and Kaiteki positions in administration of drops to the olfactory cleft. Clin. Otolaryngol. 46, 406-411. doi: 10.1111/coa.13690

Moher, D., Liberati, A., Tetzlaff, J., Altman, D. G., and PRISMA Group (2009). Preferred reporting items for systematic reviews and metaanalyses: the PRISMA statement. J. Clin. Epidemiol. 62, 1006-1012. doi: 10.1016/j.jclinepi.2009.06.005

Mori, E., Merkonidis, C., Cuevas, M., Gudziol, V., Matsuwaki, Y., and Hummel, T. (2016). The administration of nasal drops in the "Kaiteki" position allows for delivery of the drug to the olfactory cleft: a pilot study in healthy subjects. Eur. Arch. Otorhinolaryngol 273, 939-943. doi: 10.1007/s00405-015-3701-y

Nasreddine, Z. S., Phillips, N. A., Bédirian, V., Charbonneau, S., Whitehead, V., Collin, I., et al. (2005). The Montreal Cognitive Assessment, MoCA: a brief screening tool for mild cognitive impairment. J. Am. Geriatr. Soc. 53, 695-699. doi: $10.1111 / j .1532-5415.2005 .53221 . x$

Nguyen, T. P., and Patel, Z. M. (2018). Budesonide irrigation with olfactory training improves outcomes compared with olfactory training alone in patients with olfactory loss. Int. Forum Allergy Rhinol. 8, 977-981. doi: $10.1002 / \mathrm{alr} .22140$

Patel, Z. M. (2017). The evidence for olfactory training in treating patients with olfactory loss. Curr. Opin. Otolaryngol. Head Neck Surg. 25, 43-46. doi: 10.1097/MOO.0000000000000328

Pekala, K., Chandra, R. K., and Turner, J. H. (2016). Efficacy of olfactory training in patients with olfactory loss: a systematic review and meta-analysis. Int. Forum Allergy Rhinol. 6, 299-307. doi: 10.1002/alr.21669

Poletti, S. C., Michel, E., and Hummel, T. (2017). Olfactory training using heavy and light weight molecule odors. Perception 46, 343-351. doi: $10.1177 / 0301006616672881$

Printza, A., Katotomichelakis, M., Valsamidis, K., Metallidis, S., Panagopoulos, P., Panopoulou, M., et al. (2021). Smell and taste loss recovery time in COVID-19 patients and disease severity. J. Clin. Med. 10:966. doi: 10.3390/jcm10050966

Qiao, X. F., Bai, Y. H., Wang, G. P., Li, X., and Zheng, W. (2020). Clinical effects of two combinations of olfactory agents on olfactory dysfunction after upper respiratory tract infection during olfactory training. Rev. Assoc. Me. Bras. (1992) 66, 18-24. doi: 10.1590/1806-9282.66.1.18

Saatci, O., Altundag, A., Duz, O. A., and Hummel, T. (2020). Olfactory training ball improves adherence and olfactory outcomes in post-infectious olfactory dysfunction. Eur. Arch. Otorhinolaryngol. 277, 2125-2132. doi: 10.1007/s00405-020-05939-3

Schäfer, L., Schriever, V. A., and Croy, I. (2021). Human olfactory dysfunction: causes and consequences. Cell Tissue Res. 383, 569-579. doi: 10.1007/s00441-020-03381-9

Schriever, V. A., Merkonidis, C., Gupta, N., Hummel, C., and Hummel, T. (2012). Treatment of smell loss with systemic methylprednisolone. Rhinology 50, 284-289. doi: 10.4193/Rhino11.207

Seiden, A. M. (2004). Postviral olfactory loss. Otolaryngol. Clin. North Am. 37, 1159-1166. doi: 10.1016/j.otc.2004.06.007

Seo, B. S., Lee, H. J., Mo, J. H., Lee, C. H., Rhee, C. S., and Kim, J. W. (2009). Treatment of postviral olfactory loss with glucocorticoids, Ginkgo biloba, and mometasone nasal spray. Arch. Otolaryngol. Head Neck Surg. 135, 1000-1004. doi: 10.1001/archoto.2009.141

Sorokowska, A., Drechsler, E., Karwowski, M., and Hummel, T. (2017). Effects of olfactory training: a meta-analysis. Rhinology 55, 17-26. doi: 10.4193/Rhin 16.195

Stenner, M., Vent, J., Hüttenbrink, K. B., Hummel, T., and Damm, M. (2008). Topical therapy in anosmia: relevance of steroid-responsiveness. Laryngoscope 118, 1681-1686. doi: 10.1097/MLG.0b013e31817c1368

Temmel, A. F., Quint, C., Schickinger-Fischer, B., Klimek, L., Stoller, E., and Hummel, T. (2002). Characteristics of olfactory disorders in relation to major causes of olfactory loss. Arch. Otolaryngol. Head Neck Surg. 128, 635-641. doi: 10.1001/archotol.128.6.635

Tian, J., Pinto, J. M., Li, L., Zhang, S., Sun, Z., and Wei, Y. (2020). Identification of Viruses in patients with postviral olfactory dysfunction by multiplex reverse-transcription polymerase chain reaction. Laryngoscope 131, 158-164. doi: $10.1002 /$ lary.28997

Vaira, L. A., Hopkins, C., Petrocelli, M., Lechien, J. R., Cutrupi, S., Salzano, G., et al. (2021). Efficacy of corticosteroid therapy in the treatment of 
long-lasting olfactory disorders in COVID-19 patients. Rhinology 59, 21-25. doi: $10.4193 /$ Rhin 20.515

Welge-Lüssen, A., and Wolfensberger, M. (2006). Olfactory disorders following upper respiratory tract infections. Adv. Otorhinolaryngol. 63, 125-132. doi: $10.1159 / 000093758$

Whitcroft, K. L., Ezzat, M., Cuevas, M., Andrews, P., and Hummel, T. (2017). The effect of intranasal sodium citrate on olfaction in post-infectious loss: results from a prospective, placebo-controlled trial in 49 patients. Clin. Otolaryngol. 42, 557-563. doi: 10.1111/coa.12789

Conflict of Interest: The authors declare that the research was conducted in the absence of any commercial or financial relationships that could be construed as a potential conflict of interest.
Publisher's Note: All claims expressed in this article are solely those of the authors and do not necessarily represent those of their affiliated organizations, or those of the publisher, the editors and the reviewers. Any product that may be evaluated in this article, or claim that may be made by its manufacturer, is not guaranteed or endorsed by the publisher.

Copyright (๑) 2021 Yuan, Huang, Wei and Wu. This is an open-access article distributed under the terms of the Creative Commons Attribution License (CC BY).

The use, distribution or reproduction in other forums is permitted, provided the original author(s) and the copyright owner(s) are credited and that the original publication in this journal is cited, in accordance with accepted academic practice. No use, distribution or reproduction is permitted which does not comply with these terms. 